\title{
Risk Management with Supply Contracts
}

\author{
Heitor Almeida \\ University of Illinois, Urbana-Champaign \\ Kristine Watson Hankins \\ University of Kentucky \\ Ryan Williams \\ University of Arizona
}

March 2017

\begin{abstract}
:
Purchase obligations are forward contracts with suppliers and are used more broadly than traded commodity derivatives. This paper is the first to document that these contracts are a risk management tool and have a material impact on corporate hedging activity. Firms that expand their risk management options following the introduction of steel futures contracts substitute financial hedging for purchase obligations. Contracting frictions - such as bargaining power and settlement risk - as well as potential hold-up issues associated with relationship-specific investment affects the use of purchase obligations in the cross-section as well as how firms respond to the introduction of steel futures.
\end{abstract}

Funding: This work was supported by the GARP Risk Management Research Award Program.

We would like to thank Söhnke M Bartram, Martijn Cremers, Andrea Gamba, Jose-Miguel Gaspar, Gerald Gay, Michael Faulkender, Jayant Kale, Yelena Larkin, Omesh Kini, Harley (Chip) Ryan, Mark Weinstein, and participants at Bristol University, University of Exeter, Florida State University, HEC Paris, Ivey School of Business, Lehigh University, Michigan State University, the University of Arizona, University of Florida, University of Iowa, New York University, the University of Southern California Finance Organization and Markets Conference, UK/UT Jim and Jack Conference, LUBRAFIN, 2016 Hannover Commodity Markets conference, 2016 EFMA meetings, and 2017 AFA meetings for thoughtful comments. Send correspondence to Kristine Watson Hankins, Gatton College of Business and Economics, University of Kentucky; telephone: (859)257-7726. E-mail: kristine.hankins@uky.edu. 
How do firms manage risk? Hedging is potentially beneficial in a world with capital market frictions such as taxes and agency issues (Smith and Stulz, 1985; Froot, Scharfstein, and Stein, 1993). But empiricists have struggled to map the rich theoretical predictions regarding risk management to observed firm hedging behavior. One potential issue is that theory papers often examine "hedging" without specifying how firms hedge (e.g., DeMarzo and Duffie, 1995) while most empirical analysis focuses on traded derivatives usage (e.g., futures) as their proxy for corporate hedging (e.g., Nance, Smith, and Smithson, 1993; Graham and Rogers, 2002; Purnanandam, 2008).

In this paper, we focus on a common yet overlooked hedging tool - the purchase obligation. Purchase obligations are non-cancelable contracts with suppliers for materials or services, generally over one to three year horizons. The vast majority of these contracts use fixed price provisions. Thus, purchase obligations also are a forward contract with properties similar to a tradable derivative. They can minimize input price volatility like a future, but these contracts are not restricted to exchange-traded products. Accounting regulations treat a purchase obligation (PO) as an off-balance sheet liability and, starting in 2003, the downstream firm must disclose upstream purchase obligations with other major contractual obligations such as long term debt, capital leases, and operating leases.

We construct a comprehensive database of the use of purchase obligations and traded derivatives by non-financial Compustat firms and document some key empirical regularities regarding their usage. Of non-financial firms in Compustat during our sample period of 20032010, $21.5 \%$ use purchase obligations and $15.8 \%$ use traded commodity derivatives. PO use varies by industry as well as by firm; manufacturers can contract on raw material inputs whereas retailers often contract on merchandise. Firms report up to 5 years of future purchase obligations 
and the average (median) firm using contracts reports an average contract length of 2.49 years ( 3 years). Moreover, these purchase obligations are economically significant contracts, averaging $11.8 \%$ of total assets and $21.4 \%$ of COGS for firms that use them.

At least some firms appear to recognize that purchase obligations are a substitute for futures contracts. For instance, Starbucks reports that $90 \%$ of its purchase obligations are green coffee (unroasted coffee beans) purchase commitments and they report in the Commodity Price Risk section of its 2014 10-K filing:

We purchase commodity inputs, including coffee, dairy products and diesel that are used in our operations and are subject to price fluctuations that impact our financial results. We use a combination of pricing features embedded within supply contracts and financial derivatives to manage our commodity price risk exposure (emphasis added)

Firms, however, may have additional motivations to use purchase obligations. Supply contracts can help avoid hold-up problems between suppliers and customers (e.g., Williamson, 1985; Joskow, 1987; Costello, 2013). Thus, documenting the broad usage of POs does not sufficiently prove that they have an important risk management role.

To identify the risk management role of POs, we explore the introduction of steel futures products on the London Metals Exchange and the Chicago Mercantile Exchange in mid-2008. The availability of steel futures should have no impact on purchase obligation (PO) use if POs are not used for risk management purposes. We find that firms with an exposure to steel simultaneously increase their financial hedging and decrease their use of purchase obligations when the new derivative is introduced, relative to a control group of similar firms that do not benefit from the introduction of steel derivatives. To our knowledge, this represents the first evidence that purchase obligations are used as a hedging tool. 
Our interpretation for these results is that the introduction of steel derivatives causes a reduction in the risk management demand for POs but this requires us to assume that, in the absence of the introduction of new derivatives, treated firms (e.g., firms exposed to changes in steel prices) would not have changed their usage of POs relative to control firms. We provide several pieces of evidence consistent with this conclusion. Firms with an exposure to steel look similar to control firms prior to the introduction of steel derivatives. Differential growth in usage of POs across treated and control firms arises only in the aftermath of the event, and is not observed around multiple placebo tests.

We also exploit cross-sectional variation in the costs of using POs. First, firms may refrain from using traded derivatives when collateral constraints bind near distress (Rampini and Viswanathan, 2010). The evidence from the introduction of steel futures supports the importance of collateral constraints. Only financially healthy firms or those with pledgeable collateral increase their demand for futures and decrease PO use. Second, POs may become too expensive or too risky for the downstream firm if suppliers have significant bargaining power or if there is significant settlement risk. Consistent with this intuition, we show that the impact of traded derivatives on POs is stronger when POs are less expensive or more reliable, and thus more likely to be a viable substitute for traded derivatives.

Demonstrating that forward contracts with suppliers are recognized as a hedging tool contributes to the mounting theoretical and empirical evidence suggesting that traded derivatives are only one part of risk management activity. Although exchange-traded derivatives may be more efficient than individual forward contracts in the absence of transaction costs (as discussed in Williamson, 1985), the availability of traded derivatives is limited and collateral constraints can limit their use even when they are available (Rampini, Sufi, and Viswanathan, 2014). 
Previous literature focusing on traded derivatives shows that they are used mostly by large, financially strong firms (Guay and Kothari, 2003; Purnanandam, 2008). Our summary statistics show that these patterns do not hold for purchase obligations. Compared to derivative users, PO users are more similar to the median firm in our sample across a number of dimensions such as firm size, leverage, cash, and exposure of exchange traded inputs.

Evidence that firms find alternative means to address cash flow volatility also lends support to the models of Smith and Stulz (1985) and Froot, Scharfstein, and Stein (1993), where the goal of risk management is to minimize costly variance. Operational decisions can mimic the benefits of hedging with traded derivatives (Smith and Stulz, 1985). Recent papers by Bolton, Chen, and Wang (2011) and Gamba and Triantis (2014) expand the theoretical work in this area while Bonaimé, Hankins, and Harford (2014), Disatnik, Duchin and Schmidt (2014), Hankins (2011), and Hirshleifer (1988) document the operational hedging benefits of specific corporate choices such as payout flexibility, cash, and vertical integration. A key contribution of this paper is to expand the definition of hedging.

The above evidence does not negate the role of supply contracts in alleviating hold up problems between suppliers and customers, as the two motivations do not have to be mutually exclusive. Some firms may be using POs both to manage risk and to mitigate hold up problems, while other firms may use POs to address only one of those issues. Relatedly, vertical integration may be driven by hold-up or risk management concerns (Klein, Crawford, and Alchian, 1978; Garfinkel and Hankins, 2011). We therefore consider both hold-up problems and vertical integration in our tests. Our results suggest that IO motivations indeed play a role in the PO decision. Crucially, though, the introduction of steel derivatives does not affect the usage of POs in the sub-sample of firms that are likely to use POs for hold-up or organization design 
reasons. Further, vertical integration does not predict how firms respond to the introduction of steel futures. These results suggest that POs are in fact the most relevant margin of adjustment following the steel shock.

\section{Theory of Risk Management Alternatives}

Central to firm value is the ability to undertake valuable projects and hedging can increase the likelihood that adequate funds exist. However, multiple hedging choices may exist. We develop a simple theoretical framework to understand the determinants of hedging through purchase obligations, and the effects of the introduction of a new futures contract. We present this model in Appendix A. We assume that the firm can use POs, futures, or liquidity (e.g., cash) to manage its exposure to positions such as variation in input prices. Although we do not explicitly examine liquidity policies in the empirics, the substitution between liquidity and risk management is important to explain how firms manage risks when it is too expensive to use POs and/or futures, or when futures are not available.

We first characterize the model's equilibrium when futures are not available for hedging and introduce three frictions which affect the usage of purchase obligations for hedging. Next, we examine the effects of the introduction of a futures contract that expands the firm's risk management set. The new contract will change firms' demand for POs but the effect will depend on the firm's initial risk management choices. We explain the model's implications below while Section II describes our proxies for the frictions and presents evidence on how they affect PO use in the cross-section. After the main test of risk management substitution, we show how these frictions in PO use affect the response to a new future contract. 
The first friction firms may face is a collateral constraint as in Rampini and Viswanathan (2010). The collateral constraint creates a motivation for hedging, as a negative shock to cash flow may cause inefficient liquidation of the firm's investment. In addition, the collateral constraint affects the firm's choice of which tool it uses for hedging. The key difference between futures and POs (forwards) is that the futures position requires the firm to post collateral initially (at the time the futures position is opened), while the forward contract can be settled ex-post. ${ }^{1}$ Because of this wedge, hedging through forwards can alleviate the firm's collateral constraint. This mechanism reduces the desirability of futures for financially weak firms, as in Rampini and Viswanathan (2010).

Second, unlike exchange traded derivatives, POs are the product of a bargaining game between customers and suppliers. The surplus of this bargaining game is allocated based on negotiation power (Nash, 1950; Stigler, 1964), not a market. Some firms will have more or less ability to negotiate favorable terms with their suppliers and this may affect the cost of using POs.

Third, POs contain an element of settlement risk. The treatment of purchase obligations and other supply contracts by bankruptcy courts has varied over time and by circuit court. While the bankruptcy code was expanded in 1982 to protect forward contracts, the safe harbor for counterparties was limited to financial derivatives. Throughout the 2000s, a series of circuit court rulings (including Mirant, Kmart, and MBS Management) left the treatment of purchase obligations and other executory contracts ambiguous. For example, SunEdison, a semiconductor and solar energy firm, canceled purchase obligation contracts during a restructuring and expected such cancelation to result in at least some litigation.

\footnotetext{
${ }^{1}$ As we show in the model, the ex-post settlement of purchase obligations relies on the supplier's greater ability to extract pledgeable income from the buyer. The trade credit literature relies on a similar rationale to motivate the positive response of trade credit to negative financial shocks (Petersen and Rajan, 1997, Garcia-Appendini and Montoriol-Garriga, 2013, Shenoy and Williams, 2017).
} 
As part of our restructuring activities announced in the fourth quarter of 2011, we provided notice to several of our vendors with whom we had long-term supply contracts that we will no longer be fulfilling our purchase obligations under those contracts...We also included in our estimate of losses consideration around whether we believe the obligation will be settled through arbitration, litigation or commercially viable alternative resolutions or settlements. (emphasis added)

Although the circuit courts appear to be shifting toward recognizing standard purchase obligations as protected forward contracts, settlement risk is a potential additional cost of POs relative to financial hedging with exchange-traded products. Like bargaining power, we expect settlement risk to affect the use of purchase obligations.

We derive the following implications from the model:

1. Risk Management Substitution: The introduction of traded derivatives will reduce firms' demand for POs, on average.

2. Collateral and financial distress: The impact of the introduction of traded derivatives on POs is stronger for firms that are financially healthy or have more tangible assets and thus better able to post collateral for the futures position. Firms with less collateral or those closer to financial distress will not reduce PO usage as much, due to collateral constraints.

3. Expected PO Use: The impact of the introduction of traded derivatives on POs should vary with the cost of using PO to manage risk. This effect should be more important if the cost of using POs for hedging is low (settlement risk and supplier bargaining power are low), thus making POs a reasonable hedging option ex-ante. In contrast, the impact of the introduction of traded derivatives on POs is weaker when the cost of using POs is high (high settlement risk or high supplier bargaining power).

In the model, purchase obligations are used only for risk management purposes. However, as discussed in the introduction, POs also can be used to mitigate hold-up concerns related to relationship-specific investments. When firms use purchase obligations to mitigate hold-up, such contracts should be unaffected by the introduction of new risk management tools. This argument leads us to the fourth implication that we test in the data: 
4. Hold-up: POs used to address hold-up concerns are not written necessarily for the purpose of managing input price volatility. Such contracts should not respond to the introduction of an exchange traded derivative.

\section{Purchase Obligations and Risk Management Tools}

To examine the role of purchase obligations in risk management, we build a comprehensive database of the use of purchase obligations and traded derivatives by non-financial Compustat firms. We then add data on the firm and supplier characteristics. We describe the construction of our dataset in detail below.

\subsection{Purchase Obligations}

A purchase obligation is an executory contract where both parties have not yet performed their duties. The agreement contractually obligates the customer to purchase a fixed or minimum quantity at a fixed, minimum, or variable price from a supplier. ${ }^{2}$ All downstream firms are required to report these contracts in 10-K filings since December 15, 2003, following SEC requirements related to Sarbanes-Oxley. The only exception is for small businesses with revenues and a public float less than $\$ 25$ million. Thus, the sample consists of all Compustat firm-years with a year-end between 12/15/2003-12/31/2010 and an available $10-\mathrm{K}$ filing on the SEC's EDGAR site. After excluding financial firms (SIC codes between 6000 and 6999) and firms which switch two-digit SIC industries, the eight-year panel dataset consists of 26,430 firmyears.

Firms disclose these commitments to their suppliers in a footnote table of off-balance sheet liabilities. Using the scripting language Perl, we search the contractual obligations footnote in

\footnotetext{
${ }^{2}$ In an informal survey of several hundred 10-K filings, we only rarely observe footnotes mentioning a material effect of market risk/variable contracts. The vast majority use fixed pricing.
} 
relevant 2003-2010 10-K filings for the "Purchase obligation" line item, and create an indicator variable, Purchase Obligation, which equals one for all firms which report purchase obligations, and zero otherwise. ${ }^{3}$ As noted earlier, more than $21 \%$ of all firm-year observations report purchase obligations in their 10-K filings. We also extract the aggregate dollar amounts of the purchase obligations for the next five years from this footnote and report the dollar amounts under contract scaled by either total assets (Aggregate Contractual Dollar Amount ${ }_{(t+1, t+6)} /$ Total Assets $_{t}$ ) or current year cost of goods sold (Aggregate Contractual Dollar Amount $t_{t+1}$, ${ }_{t+6)} / \mathrm{COGS}_{t}$ ). The average firm using contracts commits to purchase $12 \%$ of its COGS in year $t+1$, $7 \%$ in year $t+2,5 \%$ in year $t+3$, and less than $1 \%$ in future years.

\subsection{Traded Derivatives Use and Exposure}

We collect information on financial hedging, focusing on commodity derivatives to parallel the potential hedging of input prices with purchase obligations. Again, we use Perl scripts to collect information on derivatives use and report our search keywords in Appendix B. Commodity Hedger is equal to one if a firm reports using commodity derivatives, zero otherwise. $^{4}$

As the exposure to commodity prices varies by firm, we also compute $\%$ of Input Traded to capture the percentage of a firm's input which is traded on financial markets and proxy for the availability of financial hedging. To construct this variable, we start with the 2002 Bureau of Economic Analysis' (BEA) benchmark Input-Output (IO) tables and the November 2009 issue of Futures magazine to identify all six-digit Input-Output industries which are traded on a major

\footnotetext{
${ }^{3}$ Appendix B provides additional detail on this data collection process.

${ }^{4}$ To ensure that our automated data procedure used to populate Commodity Hedger accurately captures commodity derivatives usage in firms, we compare our data to the hand collected data used in Emm, Gay, and Lin (2007). For the 3,000 firm-years which overlap, over $99 \%$ of observations are coded identically. We read the 10-K filing for observations which are inconsistent with Emm, Gay, and Lin (2007). A manual reading of the 10-K filings indicates that the data used in our paper are correctly coded.
} 
financial exchange. The industries actively traded on an exchange are listed in Appendix $\mathrm{C}$ and steel related industries are listed in bold. FuturesMarket is equal to one if the six-digit IO industry output is traded actively on a futures market, zero otherwise. This variable is coded as zero for steel-exposed industries as steel futures are introduced in the middle of the sample and will be examined directly. For each downstream industry in the IO tables, we identify all sixdigit upstream industries and weight each upstream industry's FuturesMarket value by the percentage of input supplied to each customer industry. Thus, \% of Input Traded is the weighted sum of all upstream industries' FuturesMarket value. We map this weighted-average supplier industry variable from the BEA IO Tables to each firm's two-digit NAICS industry in Compustat. We then calculate \% of Input Steel using the same methodology as \% of Inputs Traded using the steel exposed industries listed in Appendix C.

\subsection{Firm Variables}

We control for a variety of firm characteristics in the multivariate tests. Following Purnanandam (2008), which demonstrates the non-monotonic relationship between debt and risk management, we include both Market Leverage (the book value of debt divided by the sum of the market value of equity plus book value of debt) and Leverage Squared. Following Nance, Smith, and Smithson (1993), we control for growth options with R\&D and sales, and control for liquidity needs and operational hedging with cash and trade credit (e.g., Haushalter, Klasa, and Maxwell 2007; Garcia-Appendini and Montoriol-Garriga, 2013; Disatnik, Duchin, and Schmidt, 2014). $R \& D$ Intensity is defined as a firm's R\&D expense divided by total assets while firms which have not reported $\mathrm{R} \& \mathrm{D}$ expenses are assigned a $R \& D$ Intensity value of zero. Sales, defined as sales scaled by total assets, controls for possible demand-side pressures faced by the customer (i.e., Petersen and Rajan, 1997). Cash is cash holdings divided by total assets and 
Trade Credit is accounts payable scaled by assets. Finally, we control for capital expenditures and firm size. CapEx equals capital expenditures/total assets and Ln(Assets) is defined as the natural logarithm of total book value of assets.

\subsection{Frictions in Purchase Obligation Use}

Section I describes how the use of purchase obligations may vary with bargaining power and settlement risk. Below we briefly describe both firm-level and supplier industry characteristics that proxy for these frictions. While we are unable to identify the specific suppliers on a firm's purchase obligations, we can proxy for a firm's supplier landscape using data from the BEA IO tables. Appendix D provides more detail on the construction of each variable.

To capture variations in bargaining power, we calculate a weighted-average Supplier Industry $\mathrm{HHI}$ measure - based on the composition of input industries - and identify firms above the industry-year mean. These firms are categorized as facing 'High' Supplier Bargaining Power and are expected to use PO less frequently. We also use firm profitability (ROA), following Ahern (2012), as a firm-level proxy for bargaining power. High Profitability is predicted to associate with higher PO use.

We then use three proxies for settlement risk. Since settlement risk is a function of both the likelihood of distress and the cost of that distress, we create measures based on both features. Supplier Z-Score reflects the probability of distress and uses firm-year Z-scores to calculate the median industry Z-scores, which are then aggregated using the same weighting procedure as in Supplier Industry HHI. We create Supplier Tangibility to capture the cost component, using the same input industry aggregation, with Tangibility computed following Almeida and Campello (2007). For a firm-level measure of settlement risk, we assert that longer contracts correspond to lower perceived risk. If the firm believed that its suppliers are risky, there would be little risk 
management benefit to writing long-term POs. ${ }^{5}$ Long PO Contract equals one if the firm has POs lasting three or more years into the future. This three year threshold is just above the sample average contract duration of 2.6 years. This variable, by construction, only is available to examine the degree of purchase obligation use, not the existence. All proxies of settlement risk are expected to associate with lower use of purchase obligations.

\subsection{Hold-up and Organizational Design Motivations}

Section I also notes that purchase obligation use should vary with hold-up concerns and other organization design/industrial organization (IO) issues. To proxy for potential hold-up problems, we present Supplier $R \& D$ and Supplier Differentiated Goods - each calculated in a manner similar to Supplier Industry HHI. Fee, Hadlock, and Thomas (2006) argue that R\&D intensive environments generate situations where assets are more likely to be relationship-specific assets while Giannetti, Burkart, and Ellingsen (2011) notes that differentiated goods are considered more specialized and more difficult to resell. Thus, both should correlate with hold-up concerns and higher PO use. 'High' for each variable is defined relative to the annual industry mean. We also identify vertically integrated firms based on the methodology of Acemoglu, Johnson, and Mitton (2009). Vertically Integrated equals one if the Vertical Relatedness is greater than $1 \%$ and zero otherwise.

\subsection{Summary Statistics}

Table 1 presents summary statistics on our 2003-2010 panel of non-financial Compustat firms with the mean, median, and standard deviation for the whole sample as well as the subsample means for purchase obligation users (PO Users) and commodity hedgers (Comm Hedgers). Of the 26,430 firm-year observations, the use of derivatives and purchase obligations is common (15.8\% and $21.5 \%$ of firm-year observations, respectively) and some firms use both.

\footnotetext{
${ }^{5}$ Crocker and Masten (1988) note that increases in uncertainty lead to shorter contracts.
} 
We also find that the median firm has \% of Inputs Traded of roughly $1 \%$ and a mean value of $3.9 \%$, highlighting that a large portion of U.S. non-financial firms' inputs cannot be hedged directly using standard derivative contracts. This is consistent with Guay and Kothari (2003), which notes that traded derivatives usage does not have a large economic impact on firms.

Separating the sample by risk management choice, Column 4 summarizes the mean variable values for firms which use purchase obligations and Column 5 reports the same for firms which use commodity derivatives. Firms using traded derivatives are larger, have higher leverage, lower cash, lower R\&D intensity, and higher capital expenditures while PO firms appear to be more similar to the average Compustat firm. The differences are economically large. For example, derivatives users hold $7.6 \%$ of their assets as cash, while the average is $14.8 \%$ for the average PO user and $15.3 \%$ for the average Compustat firm.

Table 2 splits the sample based on expected cross-sectional variation in purchase obligation use. Section I predicts that firm bargaining power should affect the cost of purchase obligations. Panel A shows that PO use varies with our two proxies for bargaining power. When Supplier Industry Concentration is 'Low' as well as when Firm Profitability is 'High', firms are more likely to use these supply contacts (Purchase Obligations) and they use them at higher levels (AggregatePO/Assets, AggregatePO/COGS). All differences between the two groups are statistically significant. Section I further hypothesizes that settlement risk should matter. Panel B presents three proxies for settlement risk - Supplier Z Score, Supplier Tangibility, and Firm PO Contract Length. Supplier industries with lower Z scores or tangibility present higher settlement risk. Longer PO contracts proxy for lower settlement risk. As expected, hedging with POs appears to be a function of the risk of the contract. Firms supplied by industries with lower $\mathrm{Z}$ scores and lower tangibility use PO less often and at lower levels. Of the subset of firms with 
POs, longer contract length is associated with higher AggregatePO/Assets and AggregatePO/COGS. As with the proxies for bargaining power, all differences based on proxies for settlement risk are statistically significant.

The last panel of Table 2 examines IO motivations. Firms facing hold-up concerns with suppliers may use purchase obligations for reasons other than risk management. Indeed, we note that firms operating in supply chains where they face more potential hold-up problems (proxied by Supplier $R \& D$ or Supplier Differentiated Goods) use more POs. This supports Implication 4 from Section I. We confirm our Long PO Contract as a proxy for perceived settlement risk by limiting the sample to firms with both 'low' Supplier $R \& D$ and purchase obligation use. Long PO Contract, even in these firms with low hold-up concerns, still associates with higher aggregate PO usage. We also show that Vertically Integrated firms use purchase obligations as much as if not more so than non-integrated firms, indicating that supply contracts do not perfectly substitute for vertical integration. We will return to these IO motivations later in the paper to sharpen our evidence on the use of purchase obligations for risk management.

\subsection{Cross-sectional Evidence}

Next, we extend our analysis of purchase obligation use by exploring cross-sectional variation. We begin by investigating how the contracting frictions and IO motivations introduced in Section I associate with PO use in the full sample. Table 3 Panel A presents a logit regression predicting PO use with the variables we use to proxy for frictions in the costs and benefits of POs. As many of these are collinear, we regress them individually. With the exception of Supplier Industry Concentration, all have a statistically significant and positive correlation with PO use. As predicted, firm bargaining power (Firm Profitability), lower settlement risk (Supplier Z Score, Supplier Tangibility), and more potential hold-up concerns 
(Supplier R\&D, Supplier Differentiated Goods) all are correlated with purchase obligations. This holds both in the cross-section, and within industry. Although we use firm fixed effects in our later tests when we focus on a causal relation, we exclude them here since our goal is to describe which types of firms use purchase obligations not within firm variation.

In Panel B, we use the specific indicator variables employed throughout this paper for subsample analysis and regress them with and without firm level control variables to provide more cross-sectional evidence. We observe consistent patterns. High Firm Profitability associates with PO use both in the cross-section and within industry, keeping with the bargaining power hypothesis. The proxies for lower settlement risk are significant and positive in the crosssection, but not within industry where we should expect less variation. The proxies for hold-up are not always related to PO use but it is difficult to infer whether this is due to collinearity or if hold-up concerns are a secondary motivation. \% Input Traded, the availability of financial hedging, is negatively associated with PO use as would be expected if they are risk management substitutes. Leverage also has a negative coefficient, consistent with the existing literature on hedging in distress (Purnanandam (2008)). Lastly, Trade Credit is negatively associated with PO use, consistent with trade credit reducing financial constraint and hedging needs. Both Cunat (2007) and Garcia-Appendini and Monteriol-Garriga (2013) note that suppliers are liquidity providers during periods of financial constraint.

\section{Substitution of Purchase Obligations and Derivatives}

If purchase obligation contracts are risk management tools, then other risk management decisions may affect their use. The introduction of steel futures provides a natural setting in 
which to examine risk management substitutions. In this section, we document that firms treat purchase obligations and traded derivatives as alternative hedges for controlling input price volatility.

\subsection{Evidence from the Introduction of Steel Futures}

In 2008, steel futures products were introduced on the London Metals Exchange in April and the Chicago Mercantile Exchange in August. Understanding the origination of the steel futures market is important to the validity of the empirical strategy. If the futures were introduced in response to an explicit dissatisfaction with purchase obligations, then this financial innovation would not be exogenous to shifts in firms' demand for purchase obligations. However, this does not appear to be the case. News coverage of the rollout described highly skeptical industry participants expressing concern about speculation. A 2007 GE Industry Research Monitor report asserts, " $[\mathrm{M}]$ any steel producers remain reluctant to see the development of a transparent exchange-based pricing system (which invites the bogeyman speculator into the equation), preferring instead to offer direct forward-contract pricing (with raw material surcharges in some cases) to their customers" (Aldrich, 2007). ${ }^{6}$

Even if industry participants did not drive the creation of steel futures (Scinta, 2006), they did encounter a different set of hedging tools after 2008 and could adjust their risk management decisions. If purchase obligations are similar to an exchange-traded futures contract but not as efficient, firms with steel exposure could switch to steel futures to manage input price volatility (Implication 1 of the model). We identify firms with a non-trivial exposure to steel prices based on their input industries. Steel Exposure equals one if the percentage of a firm's input which is

\footnotetext{
${ }^{6}$ Carlton (1984) describes several necessary conditions for the introduction of futures markets, such as price uncertainty and large transaction values. These factors tend to be outside the control of individual participants and thus exogenous to individual firms.
} 
steel is greater than $1 \%{ }^{7}$ The Futures Available indicator equals one after the introduction of steel futures. The interaction of Futures Available and Steel Exposure captures the change in risk management behavior for firms with steel exposure after the introduction of the new derivative.

A range of firms and industries have steel exposure. Appendix E summarizes industry level exposure based on the percent of observations with \% of Input Steel greater than $1 \%$. As there are over 170 six-digit NAICS industries represented, we use Fama-French 48 industry codes to aggregate the data. ${ }^{8}$ Not surprisingly, agriculture, food, soda, books, and the like had no steel exposed observations. But more than half of the industry groups had non-trivial exposure. There are some unexpected industries included, such as Toys and Retail. However, Toys includes sectors such as fishing, hunting, and trapping; boat building and repair, musical instruments, household AV. Likewise, Retail includes dealers of autos, RVs, boats, and mobile homes. Also of note, the Fama French Steel category does not have 100\% steel exposure because that grouping also includes nonferrous metal production such as copper and aluminum.

To motivate our empirical tests, we first present graphically how purchase obligation use responded to the introduction of steel futures. We plot PO/Total Assets from 2006 to 2010, segmented by steel exposure in Figure 1. PO/Total Assets is net of the 2008 PO/Total Assets so that all firms' PO usage is shown with respect to the shock year. To control for observables, we use a matched sample to define the control group (see Section III.D for the details on the matching procedure). Firms with a non-trivial steel exposure are represented by a blue line and matched firms with little to no steel exposure are represented by a red line. The time trends in our data match the intuition of the model. Firms seem to follow similar trends in PO usage until 2008, regardless of steel exposure. Following the introduction of steel futures, we observe steel-

\footnotetext{
${ }^{7}$ Our results are robust to alternative thresholds of steel exposure. These results are presented in Appendix F.

${ }^{8}$ In the difference-in-differences regressions below, we measure steel exposure at the original six-digit industry classification
} 
exposed firms dramatically decrease PO/Total Assets, while observing no such effect among firms with minimal steel exposure.

We next compare firms affected by the introduction of steel futures to other firms. Table 4 presents summary statistics showing that steel exposed firms are somewhat similar to non-steel firms across a number of dimensions even though the firms generally are in different industries. There is no statistical difference in the mean or median size between the two groups. Median Sales are higher for steel firms but there is no difference in the means. Likewise, CapEx differs in the mean but not median. Leverage is slightly lower and statistically different for the steel firms. Lastly, both the mean and median Cash and Trade Credit levels are different but in offsetting manners. Steel exposed firms have lower mean Cash and Trade Credit but higher median values. In noting the similarities, we are not dismissing the differences. We address the differences between our treated and control sample three ways. First, we include firm fixed effects to analyze within-firm responses. Second, we include basic and more extended control variables in our multivariate regressions. Lastly, we conduct a nearest neighbor match to ensure the robustness of our results.

Table 5 presents the steel futures natural experiment results. Regressions are presented with the inclusion of both firm and year fixed effects. As Steel Exposure is time invariant, it is absorbed by the firm fixed effect. However, we can interpret the interaction with Steel Futures Available. Consistent with expectations, the interaction coefficient shows that the introduction of steel futures is associated with an increased likelihood of financial hedging for firms with steel exposure. To address the concern of endogenous (post-event) right hand side variables, we present three specifications. Column 1 excludes firm level control variables, presenting only the steel future shock interaction with firm and year fixed effects. Columns 2 and 3 include the base 
and extended controls, where the post-event control variables are scaled by 2007 total assets to minimize the endogeneity. In columns 4 through 6 , Table 5 also documents a decrease in the use of POs for steel exposed firms when steel futures become available. This decrease in operational hedging following an increase in the availability of financial derivatives holds across all three model specifications.

Since both Steel Exposure and Steel Futures Available are dummies, the coefficient on their interaction can be directly interpreted as the relative change in the usage of POs for treated firms. Thus, Table 5 suggests that Aggregate PO/Assets decreased by $2.6 \%$ to $3 \%$ more for treated firms, after the introduction of steel futures. Given that the average level of Aggregate PO/Assets for PO users is $11.8 \%$ (Table 1), this relative change is economically highly significant. These results suggest that the introduction of a new financial hedging product affects both traded derivatives and purchase obligation use, consistent with firms using non-cancelable supply contracts as alternative to exchange-traded derivatives (Implication 1 of the model).

One potential concern may be that firms use over-the-counter (OTC) contracts prior to the shock. In this case, the introduction of steel futures would not represent a shock to the availability of financial derivatives as firms could simply switch from OTC contracts to futures. To address this concern, we note that the OTC market for steel is rather small. The gross market amounts of all non-gold commodity forward and swap contracts were $5.2 \%$ of the total OTC market in June 2007 (Bank of International Settlements, 2008) and non-gold commodities include a vast array of OTC contracts, including energy, agriculture, and metals. While we don't have specific information on the OTC steel market, the presence of any active OTC hedging market for steel would minimize the impact of the shock to purchase obligations and bias our estimates towards zero. The availability of OTC steel contracts would mitigate the demand for 
risk management with POs leading to lower overall PO use for steel exposed firms and a smaller response to the introduction of steel futures. ${ }^{9}$

\subsection{Placebo Tests}

To further ensure that the above results are not affected by spurious correlation in either the cross section or the time series, we consider two placebo tests in Table 6. First, we identify twodigit SIC industries with no steel exposure (defined as steel comprising less than $0.01 \%$ of industry input). We next flag these firms as placebo "steel" firms and re-estimate our tests from Table 5, presenting again the identical base and extended control variables. The introduction of steel futures has no material impact on purchase obligations by the placebo steel firms across all specifications. That is, firms do not respond to the introduction of an unrelated derivative product.

In columns 3-6 of Table 6, we consider an additional falsification test related to the timing of the introduction of steel futures. Specifically, we replace the indicator variable Steel Futures Available, which equals one for years after the 2008 introduction of steel futures, with Placebo Steel Futures Available which equals one if the year is 2006 or 2007 and zero otherwise. We present these results for the whole sample as well as excluding the actual treated period of 2008 onwards. We find that firms with steel exposure are not changing in the pre-treatment period. Combined with our parallel trends analysis and the results from Table 5, the falsification tests in Table 6 provide additional evidence that the introduction of steel futures truly represents a shock to hedging opportunities which affects firms' usage of purchase obligations.

\subsection{Matching}

\footnotetext{
${ }^{9}$ Further, OTC markets generally require collateral, implying that such contracts are less available in cases of severe financial constraints (i.e., Rampini and Viswanathan, 2010). Our later results in Table 8 are therefore inconsistent with OTC markets playing a major factor in our tests.
} 
Next, we revisit the steel futures introduction using nearest neighbor matching. Table 7 has three panels of results for this test. Panel A presents summary statistics for the treated and matched control sample. They are similar but not perfectly matched. This is similar to the Table 4 broad sample results and, given the broad industry differences between firms with and without steel exposures, some variation isn't surprising. What we gain with the nearest neighbor match, however, is an improvement in the control group observables. While Cash and CapEx differ significantly between the two groups, a comparison of the means shows that the difference is in the thousandth decimal place and likely not economically relevant.

Panel B of Table 7 presents the difference-in-difference results of how the treated (Steel) and control (matched non-steel firms) groups responded to the introduction of steel futures. Aggregate $P O$ use declines a statistically significant -0.012 relative to the control group's change. Panel $\mathrm{C}$ reports the nearest neighbor matching average treatment effect on the treated (ATT) estimates for the same test which are very similar to the basic diff-in-diff results but make an adjustment for the imperfect matching. The coefficient estimate is almost the same as with the unadjusted diff-in-diff comparison of the treated and control groups. In total, the Table 7 nearest neighbor matching process confirms the Table 5 firm fixed effects regressions. The introduction of steel futures leads affected firms to decrease their use of purchase obligations.

\section{Cross-sectional Evidence from the Steel Futures Natural Experiment}

The introduction of steel futures provides a natural setting to test the hypothesis that purchase obligations and financial hedging are substitute hedging tools. However, forward contracting with purchase obligations can present distinct costs and risks. This section explores the various 
cross-sectional implications developed in the model in the context of the steel futures natural experiment.

\subsection{Collateral and Financial Health}

An important implication of the model is that the choice between risk management alternatives depends in part of the costs of the hedging tools. To use financial hedging, a firm must be able to post collateral. Rampini and Viswanathan (2010) highlight that collateral costs varies with the availability of collateral as well as the marginal value of cash, which increases as firms approach distress. Table 8 explores this cross-sectional prediction (Implication 2 of the model) by replicating the baseline Table 5 experiment, splitting the sample both on asset tangibility as well as financial health. Financially stronger firms are better situated to bear these costs and initiate derivatives programs while financially weaker firms are expected to continue to use POs. Steel-exposed firms more able to post collateral - firms with Z scores above 3 or with higher tangibility (above the industry year mean) - increase their use of financial hedging following the introduction of steel futures, while more constrained firms and those with lower tangibility do not. At the same time, firms more able to post collateral scale back their use of purchase obligations, while the other firms do not. These results show that the patterns identified

in Table 5 are driven by firms able to post collateral, which is consistent with Implication 2 and Rampini and Viswanathan (2010).

\subsection{Bargaining Power \& Settlement Risk}

Implication 3 of the model suggests that firms should decrease their use of purchase obligations only if they used POs as a hedge in the pre-treatment period. Purchase obligations are less attractive for firms with less bargaining power. For such firms, we should expect little or no response to the introduction of steel futures. Firms with low bargaining power ('high' Supplier 
Industry Concentration or 'low' Firm Profitability) are predicted to find PO obligations more costly and these firms, as shown in Tables 2 and 3, use PO less. Consistent with this evidence, Table 9 shows that use of POs decreases statistically only when firm bargaining power is high 'low' Supplier Industry Concentration (Column 2) and 'high' Firm Profitability (Column 3) and firms with lower bargaining power do not respond to the shock.

Relatedly, firms facing higher settlement risk are predicted to regard purchase obligations as less attractive for risk management. Given this, we expect only firms with lower settlement risk to respond to the natural experiment. We test this prediction in Table 10. Across our three proxies for settlement risk - Supplier Z Score, Supplier Tangibility, and Long PO Contractonly firms with lower settlement risk decrease their use of purchase obligation in response to the introduction of steel futures (Columns 1, 3, and 5). Firms encountering less risky purchase obligations appear to use PO for risk management and adjust in response to the new derivative. Consistent with the evidence on bargaining power, these results support Implication 3 of the model.

\subsection{Hold-up and Organizational Design Motivations}

To expand our understanding of purchase obligation use for risk management, we explore alternative motivations for using these contracts. Firms may address hold-up problems associated with relationship-specific investments with supply contracts as well as vertical integration (i.e., Williamson, 1985; Joskow, 1985; Acemoglu, Johnson, and Mitton, 2009). Implication 4 of our model predicts that the introduction of a new hedging tool should only affect purchase obligations used for hedging purposes. Therefore, purchase obligations written to address holdup problems should be unaffected by the introduction of steel future. In Table 11, we revisit our steel futures experiment and document that firms using POs to address IO contracting issues do 
not respond to the risk management shock. Potential hold-up issues increase when suppliers have higher levels of relationship-specific investment and we find such firms ('High' Supplier $R \& D$ in Column 1, 'High' Supplier Differentiated Goods in Column 3) do not decrease PO use around the introduction of steel futures even if they have a steel exposure. We therefore document a change in PO use only for firms more likely to use POs for hedging purposes.

\subsection{Vertical Integration and Trade Credit}

Finally, we explicitly consider how vertical integration interacts with a shock that expands the firm's risk management menu. We view this as an important robustness test given that vertical integration has been considered in the extant hedging literature (i.e., Garfinkel and Hankins, 2011). One also may worry that trade credit changes with PO usage and that this parallel channel affects a firm's risk management. We therefore look at whether trade credit is an important margin of adjustment following the steel shock.

In column 5 and 6 of Table 11, we examine whether vertical integration predicts a firm's response to the steel shock. We find that PO usage changes in a similar way for both VI and nonVI firms. The coefficient on the interaction term is almost identical for both VI and non-VI firms, though it is statistically insignificant for VI firms (possibly due to the smaller sample size).

Table 12 examines whether the futures introduction affect either trade credit or vertical integration. Model 1 considers the effect on trade credit, whereas models 2 and 3 consider the effects on Vertical Integration and Vertical Relatedness, respectively. We document no economically or statistically significant relationship between the steel shock and the use of trade credit or the level of vertical integration. Thus, we conclude that neither trade credit nor vertical integration are significantly affected by the expansion of a firm's risk management menu. 
Overall, these results are consistent with the argument that neither vertical integration nor trade credit represents a good substitute for the risk management role of purchase obligations.

\section{Conclusion}

We show that purchase obligations - non-cancellable futures contracts written with suppliers - are a risk management tool and a substitute for financial hedging. Firms use purchase obligations on average more broadly than traded commodity derivatives. However, following a shock that increases the availably of traded derivatives for firms with steel exposure, these firms increase financial hedging and decrease their use of purchase obligations. Firms more likely to use POs as hedging tools adjust PO usage whereas other firms do not. Moreover, we explore how collateral, bargaining power, settlement risk, and hold-up concerns all affect the propensity to use purchase obligations and document that the response to the natural experiment is concentrated in firms more likely to use purchase obligations for risk management. We also document that there is no concurrent change in the level of vertical integration or use of trade credit for treated firms.

Overall, our research offers new insights into corporate risk management. We document that purchase obligations are a widespread but overlooked hedging tool which closely mirrors the structure of a futures contract. Further, we document that firms recognize the risk management component of these supply contracts. This substantially expands the understanding of how firms manage risk and the channels available for firms without exchange-traded exposures, complementing the Froot, Scharfstein, and Stein (1993) discussion of how to manage unmarketable risks. 


\section{References}

Acemoglu, D., S. Johnson, and T. Mitton, 2009, Determinants of vertical integration: Financial development and contracting costs, Journal of Finance 64, 1251-1290.

Ahern, K., 2012, Bargaining Power and Industry Dependence in Mergers, Journal of Financial Economics 103, 530-550.

Aldrich, R., 2007, In focus: The "future" of steel?, GE Commercial Finance Research Industry Research Monitor,1-4.

Almeida, H., M. Campello, 2007, Financial constraints, asset tangibility, and corporate investment, Review of Financial Studies 20, 1429-1460.

Altman, E. I., 1968, Financial ratios, discriminant analysis and the prediction of corporate bankruptcy, Journal of Finance 23, 589-609.

Bank of International Settlements, 2008, Monetary and Economic Department: OTC derivatives market activity in the first half of 2008, Research report.

Bolton, P., H. Chen, and N. Wang, 2011, A unified theory of Tobin's q, corporate investment, financing, and risk management, Journal of Finance 66, 1545-1578.

Bonaimé, A., K. Hankins, and J. Harford, 2014, Financial flexibility, risk management, and payout choice, Review of Financial Studies 27, 1074-1101.

Carlton, D., 1984, Futures markets: Their purpose, their history, their growth, their successes and failures, Journal of Futures Markets 4, 237-271.

Costello, A., 2013, Mitigating incentive contracts in inter-firm relationships: Evidence from long-term supply contracts, Journal of Accounting and Economics, 56, 19-39.

Crocker, K. J. and S. E. Masten, 1988, Mitigating contractual hazards: Unilateral options and contract length, RAND Journal of Economics 19, 27-343.

Cunat, V., 2007, Trade Credit: Suppliers as debt collectors and insurance providers, Review of Financial Studies 20, 491-527.

DeMarzo, P. and D. Duffie, 1995, Corporate incentives for hedging and hedge accounting, Review of Financial Studies, 8, 743-771.

Disatnik, D., R. Duchin, and B. Schmidt, 2014, Cash flow hedging and liquidity choices, Review of Finance 18, 715-748.

Emm, E., G. Gay, and C. Lin, 2007, Choices and best practice in corporate risk management disclosure, Journal of Applied Corporate Finance 19, 82-93.

Fee, C. E., C. Hadlock, and S. Thomas, 2006, Corporate Equity Ownership and the Governance of Product Market Relationships, Journal of Finance, 61, 1217-1252. 
Froot, K., D. Scharfstein, J. Stein, 1993, Risk management: coordinating corporate investments and financing policies, Journal of Finance 5, 1629-1658.

Gamba, A. and A. Triantis, 2014, Corporate risk management: Integrating liquidity, hedging, and operating policies, Management Science 60, 246-264

Garcia-Appendini, E., Montoriol-Garriga, J., 2013. Firms as liquidity providers: Evidence from the 2007-2008 financial crisis. Journal of Financial Economics 109, 272-291.

Garfinkel, J., and K. W. Hankins, 2011, The role of risk management in mergers and waves, Journal of Financial Economics 101, 515-532.

Giannetti, M., M. Burkart, and T. Ellingsen, 2011, What you sell is what you lend? Explaining trade credit contracts, Review of Financial Studies 24, 1261-1298.

Graham, J. and D. Rogers, 2002, Do firms hedge in response to tax incentives, Journal of Finance 57, 815-839.

Guay, W. and S. Kothari, 2003, How much do firms hedge with derivatives?, Journal of Financial Economics 70, 423-461.

Hankins, K., 2011, How do financial firms manage risk? Unraveling the interaction of financial and operational hedging, Management Science 57, 2197-2212.

Haushalter, D., S. Klasa, and W. Maxwell, 2007, The influence of product market dynamics on the firm's cash holdings and hedging behavior, Journal of Financial Economics 84, 797-825.

Hirshleifer, D., 1988, Risk, Futures pricing, and the organization of production in commodity markets, Journal of Political Economy 96, 1206-1220.

Holmström, B. and J. Tirole, 1998, Private and public supply of liquidity, Journal of Political Economy 106, 1-40.

Joskow, P, 1985, Vertical integration and long-term contracts: The case of coal-burning electric generating plants, Journal of Law, Economics, and Organization, 1, 33-80

Joskow, P, 1987, Contract duration and relationship specific investments: Empirical Evidence from Coal Markets, American Economic Review, 77, 168-185

Kale, J. and H. Shahur, 2007, Corporate capital structure and the characteristics of suppliers and customers, Journal of Financial Economics 83, 321-365.

Klein, B., R. Crawford, and A. Alchian, 1978, Vertical Integration Appropriable Rents and the Competitive Contracting Process, Journal of Law and Economics, 21, 297-326.

Nance, D., C. Smith Jr., and C. Smithson, 1993, On the determinants of corporate hedging, Journal of Finance 48, 267-284.

Nash Jr., J. 1950, The bargaining problem, Econometrica 18, 155-162. 
Petersen, M. and R. Rajan, 1997, Trade credit: theories and evidence, Review of Financial Studies 10, 661-691.

Purnanandam, A., 2008, Financial distress and corporate risk management: Theory and evidence, Journal of Financial Economics 87, 706-739.

Rampini, A., and S. Viswanathan, 2010, Collateral, risk management, and the distribution of debt capacity, Journal of Finance 65, 2293-2322.

Rampini, A., A. Sufi, and S. Viswanathan, 2014, Dynamic risk management, Journal of Financial Economics 111, 271-296.

Rauch, J. E. 1999, Networks Versus Markets in International Trade, Journal of International Economics, 48, 7-35.

Scinta, C., 2006, Steel co execs aren't excited by idea of steel futures, Dow Jones Newservice, June 20, 2006.

Shenoy, J. and R. Williams, 2017, Trade credit and the joint effects of supplier and customer financial characteristics, Journal of Financial Intermediation, 29, 68-80.

Smith, C. and R. Stulz, 1985, The determinants of firms' hedging policies, Journal of Financial and Quantitative Analysis, 28, 391-405.

Stigler, G., 1964, The theory of oligopoly, The Journal of Political Economy 72, 44-61.

Williamson, O., 1985, The Economic Institutions of Capitalism. New York Free Press. 


\section{Appendix A: A Model of Risk Management Alternatives}

We use a simple liquidity management model along the lines of Holmström and Tirole (1998). Start with an initial (date-0) investment = I, which is fixed. The firm also starts with net worth $\mathrm{A}>0$. The investment produces a payoff $R$ at the final date (date 2 ). At date-1, the firm has to make an additional (random) investment to continue the project. If this investment is not made, the project is liquidated and produces zero. With probability $\lambda$, the required investment is $\rho$, and it is zero in the other state. We assume that $\rho<R$ (so that continuation is efficient in state $\lambda$ ), and that $R>I+\lambda \rho$ (so the project is positive NPV). Everyone is risk-neutral, and the discount rate is 1 for simplicity.

The main friction is that the firm faces a collateral constraint, as in Rampini and Viswanathan (2010). We model it by assuming that the firm can only borrow against the fixed investment I (that is, the cash flow $R$ is not pledgeable). The maximum amount that the firm can borrow against fixed assets is given by $\tau I$. Thus, the firm faces a potential financing constraint. We assume that $\tau I<\rho$. This assumption means that in the state associated with probability $\lambda$, the firm will not have sufficient pledgeable income to continue the project.

In addition to the shock in state $\lambda$, the firm is exposed to a (zero mean) additional shock. With probability $x=0.5$, there is a shortfall equal to $-\mu$, and with probability 0.5 the firm gains $\mu$. The difference between $\lambda$ and $x$ is that the exposure associated with $x$ can be hedged, either with an operational hedge or derivatives. For example, we can assume that the variation in the required investment $\rho$ is not contractible (it is firm-specific and due to the firm's own performance), while the exposure $\mu$ is due to variation in input prices. State $x$ is a state in which input prices are high. 
Since the exposure associated with $\lambda$ cannot be hedged, the firm must hold liquidity to withstand the shock. Suppose that the firm holds cash to manage the exposure to the shock $\lambda$. The amount of cash that the firm must hold to withstand the shock $\lambda$ is:

$$
C_{\text {min }}=\rho-\tau I
$$

$C_{\min }$ because is the minimum amount of cash that the firm must hold to be able to continue in state $\lambda$. Following Holmström and Tirole (1998), we assume that there is a liquidity premium $q$ associated with cash holdings (the firm pays a price $\mathrm{q}>1$ for cash at the initial date). Given this, the firm will be able to continue in state $\lambda$ if:

$$
A+\tau I>I+\lambda \rho+(q-1) \mathrm{C}_{\min }
$$

We assume that this condition holds (that is, the firm can always fund $\mathrm{C}_{\min }$ ). The associated payoff is:

$$
U=R-I-\lambda \rho-(q-1) C_{\min ,}
$$

which we assume to be greater than zero (the project is still positive NPV after accounting for the liquidity premium).

\section{A. Hedgeable risk}

How does the exposure associated with $x$ affect the firm? Notice that eliminating the exposure in state $1-\lambda$ is irrelevant. It reduces the variance of cash flows but has no effect on investment policy or the firm's payoff. On the other hand, in state $\lambda$, the firm must eliminate this exposure because it will cause inefficient liquidation. If the firm holds cash equal to $C_{\min }$ and input prices go up (state $x$ ), then the firm will face a shortfall equal to $-\mu$ and will not have sufficient pledgeable income to continue.

One way to manage this risk is by holding additional cash. If cash goes up to:

$$
C=C_{\min }+\mu,
$$


then the firm has enough cash to continue the investment in all states of the world. However, holding additional cash is costly. The additional cash will cause the firm to pay a liquidity premium $(q-1) \mu$. This premium reduces the payoff of the project, and tightens the financial constraint:

$$
U_{c}=U-(q-1) \mu,
$$

which is feasible when:

$$
A+\tau I>I+\lambda \rho+(q-1) \mathrm{C}
$$

The firm can also hedge the exposure. Assume first that derivatives (futures) are not available. Then the firm can use purchase obligations (POs). If it is costless to use POs, then the firm will always use POs rather than cash to eliminate the exposure $\mu$. There are however several possible sources for the cost of using POs.

\section{B. Supplier bargaining power}

The pricing may not be efficient (actuarially fair), since suppliers may capture some of the surplus through bargaining power (the average input price may go up for example). We can capture this through a premium $k$, so that using POs has a deadweight cost of $k \mu$. This deadweight cost reduces the final payoff to $\mathrm{R}-k \mu$.

With the forward premium, the firm's payoff is:

$$
U_{k}=U-k \mu \text {. }
$$

The forward is feasible when:

$$
A+\tau I>I+\lambda \rho+(q-1) \mathrm{C}_{\min }
$$

which we assumed to hold. The forward relaxes the financial constraint relative to cash, because the forward contract does not require a date-0 payment. In contrast, cash requires a fully collateralized position at date-0 (the firm must hold an amount that is sufficient to eliminate the 
entire exposure $\mu$, from date- 0 to date-1). In addition, notice that this formulation assumes that the premium $k \mu$ can be paid off the non-pledgeable income $R$. This formulation reflects the assumption that supplier are in a position to extract more pledgeable income from buyers, relative to external investors. This assumption is also common in the trade credit literature.

The firm will either use cash or POs to manage the hedgeable exposure, depending on the relative costs $k$ and $q$. If $k<q-1$, then the firm uses POs to manage the hedgeable exposure. This choice increases the firm's payoff $\left(\mathrm{U}_{\mathrm{k}}>\mathrm{U}_{\mathrm{C}}\right)$. If $k>q-1$, then the firm uses cash to manage hedgeable risk provided that cash is feasible, that is:

$$
A+\tau I>I+\lambda \rho+(q-1) \mathrm{C}
$$

If the firm cannot finance the cash position $\mathrm{C}(A+\tau I<I+\lambda \rho+(q-1) \mathrm{C})$, it will use POs to manage the hedgeable exposure as long as the payoff is positive $\left(U_{k}=U-k \mu>0\right)$. In this case the firm chooses forwards because they relax the financial constraint, even though they are more expensive overall than cash. Finally, if $U_{k}=U-k \mu<0$, then the firm will remain exposed to the hedgeable exposure.

\section{C. $\quad$ Settlement risk}

In addition, there may be settlement risk. We can capture this in the model through a probability $s$ that the supplier does not honor the contract. Thus, the firm is liquidated with a probability equal to $\lambda s / 2$. This risk of liquidation will reduce the firm's payoff and may cause the firm to use cash rather than POs to manage the hedgeable risk. Suppose in addition that $k=0$, to isolate the role of settlement risk in the model.

In this case, the firm's payoff when using the purchase obligation is:

$$
U_{s}=U-(\lambda s / 2)(R-\rho) .
$$


Thus the payoff is reduced by the liquidation cost $R-\rho$. The firm will switch to cash if $\mathrm{U}_{c}>\mathrm{U}_{\mathrm{s}}{ }^{10}$ If $(\lambda s / 2)(R-\rho)>(q-1) \mu$ the firm will use POs, and if $(\lambda s / 2)(R-\rho)<(q-1) \mu$ the firm will prefer to use cash. However, as in the analysis above, cash must be feasible given the liquidity premium. The required condition is the same as above:

$$
A+\tau I>I+\lambda \rho+(q-1) \mathrm{C}
$$

If this condition does not hold, then the firm will use POs instead to relax the financing constraint. Notice that POs are always feasible despite the settlement risk:

$$
A+\tau I>I+\lambda(1-s / 2) \rho+(q-1) \mathrm{C}_{\min }
$$

Thus, similarly to the case above, the firm may choose to use forwards because they relax the financial constraint, even though they reduce the firm's payoff relative to a case when the firm uses cash to manage the hedgeable risk.

\section{General case with both a forward premium and settlement risk}

Given the analysis above, the general expression for a firm's payoff when using forwards is:

$$
U_{s, k}=U-(\lambda s / 2)(R-\rho)-(1-\lambda s / 2) k \mu .
$$

This expression follows directly from the analysis above. The only point to note is that this expression assumes that the forward premium $k \mu$ is not paid when the firm is liquidated, given that the forward is settled ex-post. ${ }^{11}$ The firm will use forwards either when $U_{s, k}>U_{c}$, or when $U_{s, k}<U_{\mathrm{c}}$, but the feasibility constraint binds so that the firm cannot afford to hedge with cash.

\section{E. Introduction of Futures}

Consider now traded derivatives (futures). Rather than forwards, the firm can open a futures position equal to $\mu$ to eliminate the hedgeable exposure. However, this future position will force

\footnotetext{
${ }^{10}$ The firm will never use both cash and POs to manage hedgeable risk. If a firm switches to cash it needs to hold a position that fully hedges the firm against liquidation $\left(C=\mathrm{C}_{\min }+\mu\right)$ and thus POs become unnecessary. The firm still holds cash to manage the non-hedgeable risk in any case.

${ }^{11}$ We note that nothing substantial changes in the analysis if forward counterparties have greater than zero recovery in the event of liquidation.
} 
the firm to open a margin account with the exchange. We assume that the required amount is given by $\zeta \mu$, with $\zeta<1$. The futures position should have negligible settlement risk, thus the relevant cost for the futures is the cost of the margin account.

In the model, the margin account will behave similarly to an increase in cash holdings (it needs to be in place at date-0). Assuming that the exchange pays an interest rate on the margin account that is equivalent to what the firm earns on liquid assets, the margin account will create a liquidity premium equal to $(\mathrm{q}-1) \zeta \mu$. Thus, when using futures the firm will achieve the following payoff:

$$
U_{f}=U-(\mathrm{q}-1) \zeta \mu
$$

The futures position is feasible when:

$$
A+\tau I>I+\lambda \rho+(q-1)\left(\mathrm{C}_{\min }+\zeta \mu\right)
$$

Notice that this solution is equivalent to an increase in cash holdings from $\mathrm{C}_{\min }$ to $\mathrm{C}_{\min }+\zeta \mu$.

The key assumptions here are that: (i) the futures trade at a fair price, but require cash collateral; (ii) the interest rate on the margin account is the same as what the firm earns on cash; (iii) the cash collateral effectively belongs to the firm, though it is deposited at the exchange. If the collateral is not used, it is returned to the firm.

Only assumption (i) is crucial for the results in the model. Intuitively, futures collateral will tighten the financial constraint relative to forwards, but it is likely to reduce overall hedging costs for the firm (otherwise the introduction of futures would not matter).

Consider now what happens if firms move from an equilibrium with no futures available, to an equilibrium in which futures are available. There are essentially two cases to consider, depending on whether the firm used cash or forwards to manage the hedgeable exposure prior to 
the introduction of futures. As we discuss above, firms can switch to cash either because of a forward premium $(k>0)$ or because of settlement risk $(s>0)$.

Suppose first that both $k$ and $s$ are small enough, so that firms use POs in equilibrium to manage hedgeable risk. In that case, firms may move from POs to futures if the cost of using futures, $(\mathrm{q}-1) \zeta$, is small enough. This would happen when $U_{s, k}<U_{f}$. However, the firm can only move to futures if it has sufficient collateral $\left(A+\tau I>I+\lambda \rho+(q-1)\left(\mathrm{C}_{\min }+\zeta \mu\right)\right)$. Otherwise it will keep using forwards even when $U_{s, k}<U_{f}$.

If in contrast either $k$ or $s$ or both are large enough such that the firm uses cash rather than forwards to manage hedgeable risk, then the firm will always switch from cash to futures after futures are introduced. Futures strictly dominate cash in the model, since $\zeta<1$. In all of these cases, the firm will continue to use cash to manage the non-hedgeable liquidity risk. 
Appendix B. Description of Data Collection

\section{Purchase Obligations:}

If a firm uses the text "purchase obligation" in its footnote, but reports $\$ 0$ for the aggregate dollar amount of the contracts, we code Purchase Obligation equal to zero. Using this definition, roughly $20.8 \%$ of all Compustat firm-year observations are for firms which have entered into purchase contracts with their suppliers. The raw data containing the dollar values of the aggregate purchase obligations have several potential problems. One problem is that in addition to columns for years $t+1$ to $t+6$, the footnote line item also includes a "Total" column; sometimes this occurs before year $t+1$ and sometimes after $t+6$. We are able to automatically remove the "Total" column through programming. A related problem exists for the data we collect on contract length. Although many firms report the dollar amount of purchase obligations for years $t+1, t+2, t+3, t+4, t+5, t+6$ and onward, some firms group years $t+2$ and $t+3$ together, years $t+4$ and $t+5$ together, etc. For these firms, the estimate for contract length will be systematically too short. We are unable to solve this problem programmatically, although firms are unlikely to systematically differ in reporting based on the hedging propensity. The third problem is that firms use different scales (millions, thousands, etc.) when reporting footnote tables depending on firm size. We use a combination of automated and manual techniques to identify the scale a firm is using. First, we automatically search the contractual obligations footnote for common text used to report scale (e.g., "in millions", "in 000s", etc.). Second, we manually examine the timeseries of the amount of each firm's supplier purchase obligations and compare the scale in consecutive years to ensure consistency. Lastly, we manually examine firms which have annual purchase obligations that are higher than current year cost of goods sold to ensure that the scale is correct and adjust the scale if necessary. The resulting unique database identifies the existence

of a firm's contractual purchase obligations to its suppliers as well as estimates of the lengths and amounts of these obligations.

\section{List of Search Terms Used to Identify Commodity Derivatives Users:}

hedge fuel, fuel hedge, fuel call option, commodity derivative, commodity contract, commodity forward, commodity future, commodity hedge, commodity hedging, commodity option, commodity swap, hedges of commodity price, uses derivative financial instruments to manage the price risk, uses financial instruments to manage the price risk, uses derivative financial instruments to manage price risk, uses derivatives to manage the price risk, uses derivatives to manage price risk, forward contracts for certain commodities, forward contracts for commodities derivatives to mitigate commodity price risk, futures to mitigate commodity price risk, options to mitigate commodity price risk, swaps to mitigate commodity price risk, corn future, cattle future commodity price swap 
Appendix C: List of Industries with Traded Futures

\begin{tabular}{ll} 
NAICS & Industry Name \\
\hline 111110 & Soybeans \\
111120 & Oilseeds \\
111140 & Wheat \\
111150 & Corn \\
111160 & Rice \\
111920 & Cotton \\
111930 & Sugarcane \\
111991 & Sugar beets \\
112110 & Cattle \\
112210 & Swine \\
112410 & Sheep and wool \\
211111 & Crude petroleum and natural gas \\
211112 & Liquid natural gas \\
212112 & Coal \\
212113 & Anthracite coal \\
212221 & Gold ores \\
212222 & Silver ores \\
212231 & Lead and zinc ores \\
212234 & Copper and nickel ores \\
311222 & Soybean oil \\
311223 & Other oilseed \\
311225 & Margarine \\
311310 & Sugar \\
311512 & Creamery butter \\
311611 & Meat products (except poultry) \\
311920 & Coffee and tea \\
311942 & Spices and extracts \\
324110 & Petroleum refinery products \\
325212 & Synthetic rubber \\
$\mathbf{3 3 1 1 1 1}$ & Iron and steel mills (only post-2008) \\
$\mathbf{3 3 1 1 1 2}$ & Ferroalloy product manufacturing (only post-2008) \\
$\mathbf{3 3 1 2 1 0}$ & Iron and steel pipe and tube manufacturing (only post-2008) \\
$\mathbf{3 3 1 2 2 1}$ & Rolled steel shape manufacturing (only post-2008) \\
$\mathbf{3 3 1 2 2 2}$ & Steel wire drawing (only post-2008) \\
$\mathbf{3 3 1 5 1 2}$ & Steel foundries, investment (only post-2008) \\
$\mathbf{3 3 1 5 1 3}$ & Steel foundries, non-investment (only post-2008) \\
$\mathbf{3 3 2 1 1 1}$ & Iron and steel forging (only post-2008) \\
331312 & Primary aluminum \\
331314 & Secondary aluminum \\
331315 & Aluminum sheets \\
331411 & Primary copper \\
331419 & Primary metals (except copper and aluminum) \\
&
\end{tabular}




\section{Appendix D: Proxies for Frictions in PO Use}

Below is additional detail on the construction of our supplier-related proxies for bargaining power, settlement risk, and hold-up/IO concerns, all of which may affect the use of purchase obligations:

Bargaining Power: We calculate Industry HHI for each supplier industry using two-digit NAICS codes, and then sales-weight them using the IO tables to calculate Supplier Industry $H H I$. For each customer industry, we weight each six-digit supplier industry characteristic by the percentage of input they supply to the customer industry according to the "Use" table from the Input-Output tables.

$$
\text { SupplierIndustry HHI }=\sum_{\substack{i=1 \\ i \neq j}}^{n} \text { Industry Input Coefficient }_{i j} \times{\text { Industry } H H I_{i}}
$$

where $j$ is the firm's primary six-digit IO industry, and $i$ is the six-digit IO industry for each supplier industry, $n$ is the number of industries which sell inputs to the reference firm, Industry $H H I$ is the Herfindahl index of the industry and the Industry Input Coefficient is the percentage of industry $j$ 's input which comes from industry $i{ }^{12}$ For example: if "Energy" has an HHI of $20 \%$ and it supplies $50 \%$ of a customer industry's input, and "Retail" has an $\mathrm{HHI}$ of $10 \%$ and it supplies the other $50 \%$ of a customer industry's input, the weighted average supplier Herfindahl index for that customer would be 15\%. Supplier Bargaining Power is 'High' if the firm's Supplier Industry HHI is above the annual mean and 'Low' is below that threshold. Higher Supplier Bargaining Power is predicted to correlate with lower use of purchase obligations.

\footnotetext{
${ }^{12}$ For example: if "Energy" has an HHI of $20 \%$ and it supplies $50 \%$ of a customer industry's input, and "Retail" has an HHI of $10 \%$ and it supplies the other $50 \%$ of a customer industry's input, the weighted average supplier Herfindahl index for that customer would be $15 \%$.
} 
Settlement Risk: To construct the first proxy, Supplier Z-Score, we first calculate the Z-score (Altman, 1968) for all firms in Compustat and then aggregate firm-year Z-scores by two-digit NAICS code to construct industry characteristics, and define Industry Z-Score as the median industry Z-score. The weighting procedure for all supplier-industry variables is identical as for Supplier Industry HHI. Supplier settlement risk is high if the Supplier Z-Score is below the sample mean and low if above that threshold. ${ }^{13}$

Alternative Settlement Risk: Supplier Tangibility is based on the same process as Supplier ZScore. Tangibility is computed following Almeida and Campello (2007), and it is sales-weighted by supplier industry for each downstream customer industry.

Hold-up: Supplier $R \& D$ is calculated using aggregate $R \& D$ and Assets for each industry and then aggregate similar to Supplier Industry HHI. Our methodology is similar to that of Kale and Shahrur (2007). We first replace missing R\&D values with zero and then aggregate firm-year R\&D by two-digit NAICS code to construct industry characteristics and define Industry $R \& D$ as aggregate industry R\&D divided by aggregate industry assets. Next, we link the industry-year R\&D to each six-digit IO industry from the 2002 BEA Input-Output tables. For each customer industry, we use the "Use" table from the Input-Output tables and weight each six-digit supply industry characteristic by the percentage of input they supply to the customer industry. We construct Supplier $R \& D$ Intensity for each firm in industry $j$ as follows:

Supplier R\&D Intensity $=\sum_{\substack{i=1 \\ i \neq j}}^{n}$ Industry Input Coefficient $_{i j} \times{\text { Industry } R \& D_{i}}$

\footnotetext{
${ }^{13}$ We cannot use the traditional thresholds for distress here because of the weighting methodology.
} 
where $j$ is the firm's primary six-digit IO industry, $i$ is the six-digit IO industry for each supplier industry, $n$ is the number of industries which sell inputs to the reference firm, Industry $R \& D$ is the R\&D/Assets of the industry and the Industry Input Coefficient is the percentage of industry $j$ 's input which comes from industry $i$.

Alternative Hold-up: Supplier Differentiated Goods is based on Giannetti, Burkart, and Ellingsen (2011) and Rauch (1999), which classifies products as standardized or differentiated. Standardized goods have mostly homogenous prices while differentiated goods have heterogeneous pricing. We construct this variable similar to Supplier $R \& D$ above. Specifically, we use the above definitions to define industries that produce differentiated good at the 2-digit level and then constructed a sales-weighted average across all supplier industries to estimate the percentage of a firm's upstream industries that produce differentiated products. We estimate the following formula, where Diff Goods takes a value of one for each differentiated goods industry:

Supplier Differentiated Goods $=\sum_{\substack{i=1 \\ i \neq j}}^{n}$ Industry Input Coefficient $_{i j} \times$ Diff Goods $_{i}$

Vertical Integration: Finally, we identify vertically integrated firms based on the methodology of Acemoglu, Johnson, and Mitton (2009). We identify all of a firm's 6-digit NAICS operating segments using the Compustat Segment tapes and then map the NAICS codes to the BEA's 6 digit IO codes. Using the industry input-output flows in the BEA IO tables, we estimate the sales weighted percentage of a firm's inputs that it could hypothetically purchase from itself. We define Vertical Relatedness as a continuous measure between 0 and 1 that captures this value. Following Acemoglu et al. (2009), Vertically Integrated equals one if the Vertical Relatedness is greater than $1 \%$ and zero otherwise. 


\section{Appendix E: Steel Exposure by Industry}

This table summarizes steel exposure across the Fama-French 48 industry categories. The left hand column lists the industry number and label while the right-hand column reports the percentage of observations with steel exposure as defined in Section II B. For brevity, all industries with zero steel exposure are reported together.

FF48 Industry

\% Steel Exposed

1 Agriculture, 2 Food Products, 3 Candy \& Soda, 4 Beer \& Liquor,

5 Tobacco Products, 7 Entertainment, 8 Printing and Publishing, 13 Pharmaceutical

Products, 31 Utilities, 32 Communication, 33 Personal Services, 34 Business

Services , 40 Transportation, 41 Wholesale, 43 Restaurants, Hotels, Motels 0.00

11 Healthcare $\quad 0.01$

35 Computers $\quad 0.03$

14 Chemicals $\quad 0.10$

48 Other/Almost Nothing $\quad 0.10$

42 Retail $\quad 0.11$

10 Apparel $\quad 0.13$

15 Rubber and Plastic Products $\quad 0.14$

16 Textiles $\quad 0.15$

30 Petroleum and Natural Gas $\quad 0.21$

38 Business Supplies $\quad 0.21$

6 Recreation $\quad 0.27$

36 Electronic Equipment 0.28

39 Shipping Containers $\quad 0.29$

17 Construction Materials $\quad 0.51$

9 Consumer Goods $\quad 0.59$

26 Defense $\quad 0.67$

19 Steel Works Etc 0.74

25 Shipbuilding, Railroad Equipment $\quad 0.78$

37 Measuring and Control Equipment $\quad 0.83$

23 Automobiles and Trucks $\quad 0.85$

12 Medical Equipment $\quad 0.87$

22 Electrical Equipment $\quad 0.88$

21 Machinery $\quad 1.00$

18 Construction $\quad 1.00$

20 Fabricated Products $\quad 1.00$

24 Aircraft $\quad 1.00$

27 Precious Metals $\quad 1.00$

28 Non-Metallic and Industrial Metal Mining $\quad 1.00$

29 Coal $\quad 1.00$ 


\section{Appendix F: Robustness of Steel Exposure Threshold}

The table presents multivariate estimates using nonfinancial Compustat firms from 2003-2010. The dependent variable in the OLS estimates is AggregatePO/Assets. Steel Futures Available is an indicator equal to one if the year is after 2008, zero otherwise. Steel Exposure (median) is equal to one if percentage input from steel is greater than the sample median, zero otherwise. Steel Exposure (mean) is equal to one if percentage input from steel is greater than the mean, zero otherwise. Steel Exposure $(0.5 \%)$ is equal to one if percentage input from steel is greater $0.5 \%$, zero otherwise. All control variables are as described in Table 1 and included with a one year lag. Post-event firm control variables (after 2007) are scaled by 2007 total assets. t-Statistics are presented in parenthesis and are calculated from robust standard errors clustered by firm. All models include year and firm indicator variables. *, **, and $* * *$ represent significance at the $10 \%, 5 \%$, and $1 \%$ levels, respectively.

\begin{tabular}{|c|c|c|c|c|c|c|}
\hline & \multicolumn{6}{|c|}{ Aggregate PO/Assets } \\
\hline & (1) & (2) & (3) & (4) & (5) & (6) \\
\hline \multirow[t]{2}{*}{ Steel Futures Available } & 0.009 & 0.006 & 0.008 & 0.009 & 0.006 & 0.008 \\
\hline & $(1.018)$ & $(0.830)$ & $(0.998)$ & $(1.080)$ & $(0.838)$ & $(1.044)$ \\
\hline \multirow[t]{2}{*}{ Futures Available*Steel Exposure (median) } & $-0.018^{*}$ & & & $-0.018 *$ & & \\
\hline & $(-1.896)$ & & & $(-1.942)$ & & \\
\hline \multirow[t]{2}{*}{ Futures Available*Steel Exposure (mean) } & & $-0.021^{*}$ & & & $-0.021 *$ & \\
\hline & & $(-1.814)$ & & & $(-1.821)$ & \\
\hline \multirow[t]{2}{*}{ Futures Available*Steel Exposure $(0.5 \%)$} & & & $-0.023^{* *}$ & & & $-0.023^{* *}$ \\
\hline & & & $(-2.354)$ & & & $(-2.374)$ \\
\hline \multirow[t]{2}{*}{ Leverage } & -0.020 & -0.021 & -0.020 & -0.016 & -0.015 & -0.017 \\
\hline & $(-0.881)$ & $(-0.929)$ & $(-0.895)$ & $(-0.325)$ & $(-0.307)$ & $(-0.346)$ \\
\hline \multirow[t]{2}{*}{ Cash } & -0.026 & -0.027 & -0.026 & -0.027 & -0.027 & -0.027 \\
\hline & $(-1.290)$ & $(-1.331)$ & $(-1.292)$ & $(-1.319)$ & $(-1.348)$ & $(-1.322)$ \\
\hline \multirow[t]{2}{*}{ Firm Size } & -0.000 & -0.001 & -0.001 & -0.001 & -0.001 & -0.001 \\
\hline & $(-0.040)$ & $(-0.109)$ & $(-0.109)$ & $(-0.127)$ & $(-0.176)$ & $(-0.198)$ \\
\hline \multirow[t]{2}{*}{ Capex } & 0.007 & 0.008 & 0.008 & 0.009 & 0.010 & 0.011 \\
\hline & $(0.118)$ & $(0.142)$ & $(0.145)$ & $(0.162)$ & $(0.177)$ & $(0.190)$ \\
\hline \multirow[t]{2}{*}{$\%$ Input Traded (non-steel) } & & & & -0.032 & -0.012 & -0.030 \\
\hline & & & & $(-0.611)$ & $(-0.231)$ & $(-0.557)$ \\
\hline \multirow[t]{2}{*}{ Leverage Squared } & & & & -0.003 & -0.006 & -0.002 \\
\hline & & & & $(-0.048)$ & $(-0.099)$ & $(-0.032)$ \\
\hline \multirow[t]{2}{*}{ Sales } & & & & 0.001 & 0.001 & 0.001 \\
\hline & & & & $(0.177)$ & $(0.183)$ & $(0.143)$ \\
\hline \multirow[t]{2}{*}{ R\&D Intensity } & & & & -0.006 & -0.004 & -0.007 \\
\hline & & & & $(-0.191)$ & $(-0.127)$ & $(-0.207)$ \\
\hline \multirow[t]{2}{*}{ Trade Credit } & & & & -0.026 & -0.026 & -0.025 \\
\hline & & & & $(-0.445)$ & $(-0.440)$ & $(-0.416)$ \\
\hline Firm Fixed Effects & Yes & Yes & Yes & Yes & Yes & Yes \\
\hline Year Dummies & Yes & Yes & Yes & Yes & Yes & Yes \\
\hline \# Observations & 20,419 & 20,419 & 20,419 & 20,377 & 20,377 & 20,377 \\
\hline
\end{tabular}




\section{Figure 1: Aggregate POs, Steel Futures}

Figure 1 presents the time series analysis of firms using purchase obligations. The y-axis is PO/Total Assets; adjusted by the 2008 PO/Total Assets. The graph is centered on the 2008-09 introduction of steel futures. The blue line plots the aggregate level of POs among firms with steel exposure and the orange line plots the aggregate level of POs among firms with low/no steel exposure.

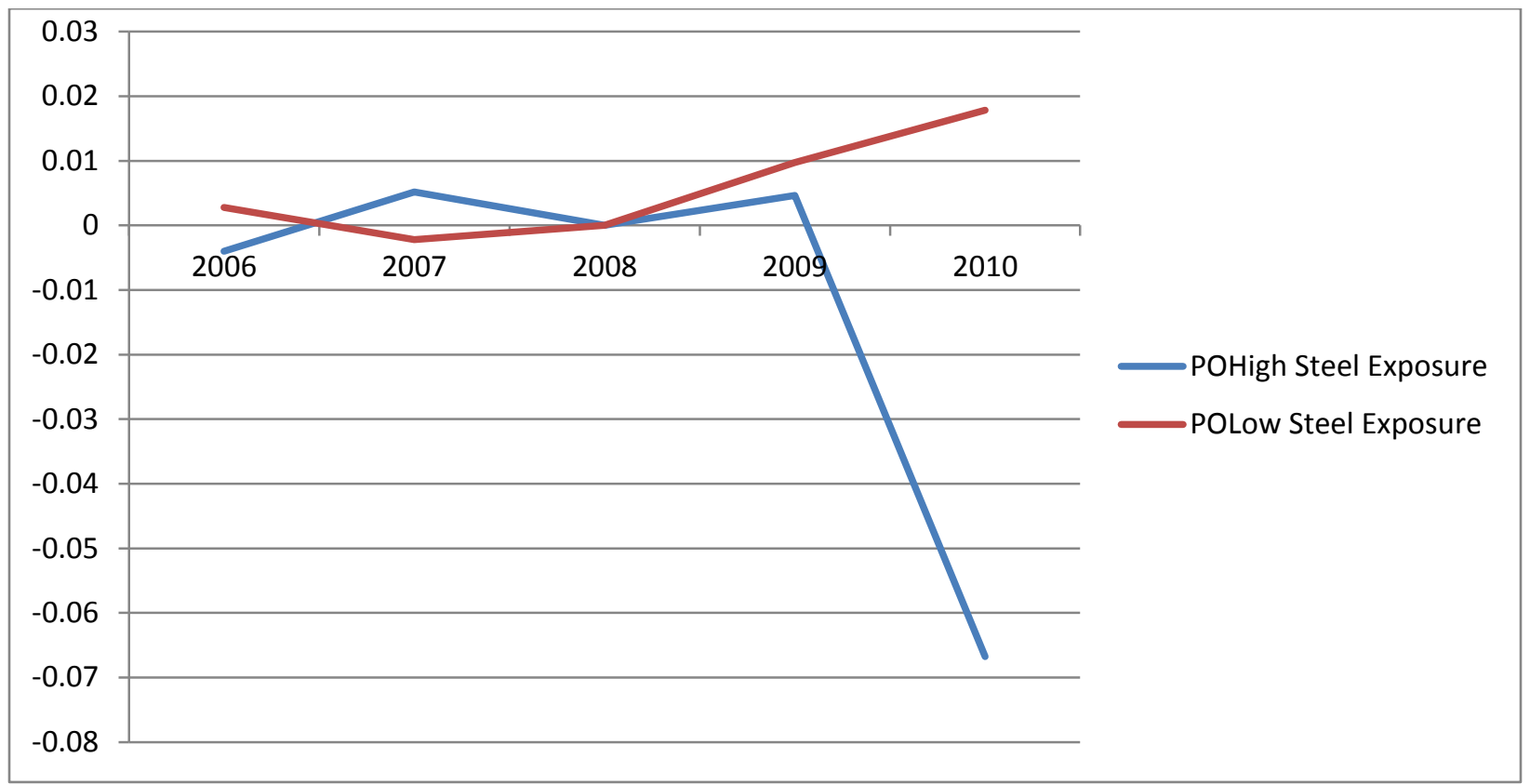




\section{Table 1}

\section{Summary Statistics}

The tables presents summary statistics using all nonfinancial Compustat firms from 2003-2010. Panel A presents the mean, median, and standard deviation for the entire sample as well as the mean for purchase obligation users ( $P O$ Users) and firms using commodity hedges (Comm. Hedgers). Purchase Obligation is equal to one if the firm reports purchase obligations in its 10-K filing and zero otherwise. AggregatePO/Assets is the sum of the future purchase obligations scaled by total assets. AggregatePO/COGS is the sum of the future purchase obligations scaled by current cost of goods sold. Commodity Hedger is equal to one if a firm reports using commodity derivatives, zero otherwise. \% Input Traded is equal to the percentage of input which is traded on an active futures exchange. \% Input Steel is equal to the percentage of a firm's input accounted for by steel. Market Leverage is the book value of debt divided by the sum of the market value of equity and the book value of debt. Cash is cash holdings divided by total assets. Investment/Assets R\&D + CAPEX + Advertising divided by total assets. Sales/Assets is total net revenues divided by total assets. $R \& D$ Intensity is the firm's own RD/Assets. CapEx is the firm's capital expenditures divided by total assets. Firm Size is the natural logarithm of the firm's book assets. Trade Credit is AP/Total Assets. In Panel B, Supplier Herf Index is the weighted average Herf Index of all the firm's supplier industries and Supplier Bargaining Power is 'High' if the Supplier Herf Index is above than the annual mean.

\begin{tabular}{|c|c|c|c|c|c|c|}
\hline \multirow[b]{2}{*}{ Variable } & \multicolumn{3}{|c|}{ All Firms } & \multirow{2}{*}{$\frac{\text { PO Users }}{\text { Mean }}$} & \multicolumn{2}{|c|}{ Comm. Hedgers } \\
\hline & Mean & Median & StDev & & Mean & $\mathrm{N}$ \\
\hline & (1) & (2) & (3) & (4) & (5) & (6) \\
\hline Purchase Obligation & 0.215 & 0.000 & 0.411 & 1.000 & 0.252 & 26,430 \\
\hline AggregatePO/Assets & 0.026 & 0.000 & 0.268 & 0.118 & 0.028 & 25,358 \\
\hline AggregatePO/COGS & 0.046 & 0.000 & 0.362 & 0.214 & 0.048 & 25,944 \\
\hline Commodity Hedger & 0.158 & 0.000 & 0.364 & 0.184 & 1.000 & 26,430 \\
\hline$\%$ of Input Traded & 0.039 & 0.009 & 0.087 & 0.040 & 0.092 & 26,430 \\
\hline$\%$ of Input Steel & 0.014 & 0.001 & 0.032 & 0.018 & 0.016 & 26,430 \\
\hline Market Leverage & 0.193 & 0.117 & 0.220 & 0.180 & 0.286 & 25,026 \\
\hline Cash/Assets & 0.153 & 0.088 & 0.180 & 0.148 & 0.076 & 24,935 \\
\hline Investment/Assets & 0.132 & 0.082 & 0.158 & 0.121 & 0.112 & 24,655 \\
\hline Sales/Assets & 1.021 & 0.851 & 0.824 & 1.039 & 0.996 & 25,099 \\
\hline$R \& D$ Intensity & 0.076 & 0.004 & 0.174 & 0.057 & 0.017 & 26,430 \\
\hline CapEx & 0.050 & 0.029 & 0.066 & 0.052 & 0.086 & 24,655 \\
\hline Firm Size & 5.744 & 5.760 & 2.148 & 6.578 & 7.287 & 26,430 \\
\hline Trade Credit & 0.097 & 0.055 & 0.140 & 0.081 & 0.087 & 25,059 \\
\hline
\end{tabular}




\section{Table 2}

\section{Summary statistics - by Bargaining Power and Settlement Risk}

The tables presents summary statistics using all nonfinancial Compustat firms from 2003-2010. In Panel A, low Supplier Industry Concentration (supplier HHI less than the annual mean) or high Profitability (ROA greater (less) than the annual mean) proxy for higher bargaining power. In Panel B, higher Supplier Z-Score (greater than the industry annual mean), higher Supplier Tangibility (greater than the industry annual mean), and longer contract length proxy for lower settlement risk. Long PO Contract equals one if the firm has a purchase obligation written for 3 or more years. Panel C presents two proxies for hold-up as well as vertical integration. High (Low) Supplier R\&D is defined as having supplier R\&D greater (less) than the industry annual mean. High (Low) Differentiated Goods is defined following the methodology of Giannetti et al (2011). Vertical Integration is defined following the methodology of Acemoglu et al. (2009). P-Values for the differences in means and medians are presented. Other variables are as defined in Table 1.

Panel A: Bargaining Power

\begin{tabular}{|c|c|c|c|c|c|c|c|c|}
\hline \multirow[b]{4}{*}{ Purchase Obligation } & \multicolumn{8}{|c|}{ Supplier Industry Concentration } \\
\hline & \multicolumn{3}{|c|}{ High } & \multicolumn{3}{|c|}{ Low } & \multirow[b]{2}{*}{ Diff } & \multirow[b]{2}{*}{ P Value } \\
\hline & \# Obs & Mean & St. Error & \# Obs & Mean & St. Error & & \\
\hline & 11,147 & 0.201 & 0.004 & 15,283 & 0.225 & 0.003 & 0.024 & 0.000 \\
\hline AggregatePO/Assets & 10,699 & 0.023 & 0.002 & 14,659 & 0.028 & 0.003 & 0.005 & 0.072 \\
\hline \multirow[t]{4}{*}{ AggregatePO/COGS } & 10,964 & 0.038 & 0.001 & 14,981 & 0.046 & 0.001 & 0.009 & 0.000 \\
\hline & \multicolumn{8}{|c|}{ Firm Profitability } \\
\hline & \multicolumn{3}{|c|}{ High } & \multicolumn{3}{|c|}{ Low } & & \\
\hline & \# Obs & Mean & St. Error & \# Obs & Mean & St. Error & Diff & P Value \\
\hline Purchase Obligation & 19,556 & 0.237 & 0.003 & 6,859 & 0.155 & 0.004 & -0.082 & 0.000 \\
\hline AggregatePO/Assets & 18,932 & 0.027 & 0.002 & 6,426 & 0.022 & 0.002 & -0.005 & 0.090 \\
\hline AggregatePO/COGS & 19,407 & 0.047 & 0.001 & 6,538 & 0.030 & 0.001 & -0.016 & 0.000 \\
\hline
\end{tabular}

\section{Panel B: Settlement Risk}

\begin{tabular}{|c|c|c|c|c|c|c|c|c|}
\hline \multirow{6}{*}{$\begin{array}{l}\text { Purchase Obligation } \\
\text { AggregatePO/Assets } \\
\text { AggregatePO/COGS }\end{array}$} & \multicolumn{8}{|c|}{ Supplier Z Score } \\
\hline & \multicolumn{3}{|c|}{ High } & \multicolumn{3}{|c|}{ Low } & \multirow[b]{2}{*}{ Diff } & \multirow[b]{2}{*}{ P Value } \\
\hline & \# Obs & Mean & St. Error & \# Obs & Mean & St. Error & & \\
\hline & 14,640 & 0.233 & 0.003 & 11,787 & 0.193 & 0.004 & -0.040 & 0.000 \\
\hline & 14,053 & 0.029 & 0.003 & 11,302 & 0.021 & 0.002 & -0.008 & 0.011 \\
\hline & 14,334 & 0.047 & 0.001 & 11,608 & 0.038 & 0.001 & -0.009 & 0.000 \\
\hline & \multicolumn{8}{|c|}{ Supplier Tangibility } \\
\hline & \multicolumn{3}{|c|}{ High } & \multicolumn{3}{|c|}{ Low } & & \\
\hline & \# Obs & Mean & St. Error & \# Obs & Mean & St. Error & Diff & P Value \\
\hline Purchase Obligation & 12,454 & 0.238 & 0.004 & 13,973 & 0.195 & 0.003 & -0.044 & 0.000 \\
\hline AggregatePO/Assets & 11,982 & 0.033 & 0.003 & 13,373 & 0.019 & 0.002 & -0.013 & 0.000 \\
\hline \multirow[t]{4}{*}{ AggregatePO/COGS } & 12,289 & 0.045 & 0.001 & 13,653 & 0.040 & 0.001 & -0.005 & 0.004 \\
\hline & \multicolumn{8}{|c|}{ Firm PO Contract Length } \\
\hline & \multicolumn{3}{|c|}{ High $(3+$ years $)$} & \multicolumn{3}{|c|}{ Low } & & \\
\hline & \# Obs & Mean & St. Error & \# Obs & Mean & St. Error & Diff & P Value \\
\hline AggregatePO/Assets & 1,406 & 0.152 & 0.007 & 4,094 & 0.107 & 0.010 & -0.045 & 0.005 \\
\hline AggregatePO/COGS & 1,459 & 0.311 & 0.008 & 4,184 & 0.155 & 0.003 & -0.156 & 0.000 \\
\hline
\end{tabular}


Table 2 (Continued)

Summary statistics - by Bargaining Power and Settlement Risk

Panel C: IO Motivations

\begin{tabular}{|c|c|c|c|c|c|c|c|c|}
\hline \multirow[b]{4}{*}{ Purchase Obligation } & \multicolumn{8}{|c|}{ Supplier $R \& D$} \\
\hline & \multicolumn{3}{|c|}{ High } & \multicolumn{3}{|c|}{ Low } & \multirow[b]{2}{*}{ Diff } & \multirow[b]{2}{*}{ P Value } \\
\hline & \# Obs & Mean & St. Error & \# Obs & Mean & St. Error & & \\
\hline & 12,380 & 0.227 & 0.004 & 14,050 & 0.205 & 0.003 & -0.022 & 0.000 \\
\hline AggregatePO/Assets & 11,849 & 0.031 & 0.003 & 13,509 & 0.021 & 0.001 & -0.010 & 0.001 \\
\hline \multirow[t]{4}{*}{ AggregatePO/COGS } & 12,163 & 0.045 & 0.001 & 13,782 & 0.040 & 0.001 & -0.006 & 0.001 \\
\hline & \multicolumn{8}{|c|}{ Supplier Differentiated Goods } \\
\hline & \multicolumn{3}{|c|}{ Yes } & \multicolumn{3}{|c|}{ No } & & \\
\hline & \# Obs & Mean & St. Error & \# Obs & Mean & St. Error & Diff & P Value \\
\hline Purchase Obligation & 10,675 & 0.235 & 0.004 & 15,755 & 0.202 & 0.003 & -0.033 & 0.000 \\
\hline AggregatePO/Assets & 10,145 & 0.028 & 0.004 & 15,213 & 0.024 & 0.002 & -0.004 & 0.142 \\
\hline \multirow[t]{4}{*}{ AggregatePO/COGS } & 10,367 & 0.049 & 0.001 & 15,578 & 0.039 & 0.001 & -0.010 & 0.000 \\
\hline & \multicolumn{8}{|c|}{ Contract Length for Low Supplier R\&D Firms } \\
\hline & \multicolumn{3}{|c|}{ High (3+ years) } & \multicolumn{3}{|c|}{ Low } & & \\
\hline & \# Obs & Mean & St. Error & \# Obs & Mean & St. Error & Diff & P Value \\
\hline AggregatePO/Assets & 769 & 0.166 & 0.011 & 2,010 & 0.078 & 0.004 & -0.088 & 0.000 \\
\hline \multirow[t]{4}{*}{ AggregatePO/COGS } & 797 & 0.314 & 0.011 & 2,051 & 0.147 & 0.004 & -0.167 & 0.000 \\
\hline & \multicolumn{8}{|c|}{ Vertically Integrated } \\
\hline & \multicolumn{3}{|c|}{ Yes } & \multicolumn{3}{|c|}{ No } & & \\
\hline & \# Obs & Mean & St. Error & \# Obs & Mean & St. Error & Diff & P Value \\
\hline Purchase Obligation & 570 & 0.302 & 0.019 & 25,860 & 0.213 & 0.003 & -0.088 & 0.000 \\
\hline AggregatePO/Assets & 562 & 0.030 & 0.005 & 24,796 & 0.026 & 0.002 & -0.005 & 0.344 \\
\hline AggregatePO/COGS & 570 & 0.065 & 0.007 & 25,375 & 0.042 & 0.001 & -0.023 & 0.000 \\
\hline
\end{tabular}




\section{Table 3}

\section{Cross-sectional Evidence on Purchase Obligation Use}

The tables presents cross-sectional evidence using all nonfinancial Compustat firms from 2003-2010. Both panels estimate logit regressions, with and without industry indicator variables and the independent variable is purchase obligation use ( $P O$ Indicator). In Panel A, firm and supplier characteristics, which proxy for frictions in purchase obligation use and are described in Table 2, are regressed individually. In Panel B, the subsample indicators described in Table 2 are regressed both with and without the control variables described in Table 1. $t$-Statistics are presented in parenthesis and are calculated from robust standard errors clustered by firm. All models include year indicator variables. *, **, and *** represent significance at the $10 \%, 5 \%$, and $1 \%$ levels, respectively.

\section{Panel A:}

O Indicator

\begin{tabular}{|c|c|c|c|c|c|c|c|c|c|c|c|c|}
\hline & & & & & & & & & & & & \\
\hline & (1) & (2) & (3) & (4) & (5) & (6) & (7) & (8) & (9) & $(10)$ & (11) & (12) \\
\hline Firm ROA & $\begin{array}{c}0.677 * * * \\
(5.659)\end{array}$ & & & & & & $\begin{array}{c}0.733 * * * \\
(5.574)\end{array}$ & & & & & \\
\hline Supplier Herf & & $\begin{array}{c}-1.649 \\
(-0.528)\end{array}$ & & & & & & $\begin{array}{c}5.691 \\
(1.307)\end{array}$ & & & & \\
\hline Supplier Z Score & & & $\begin{array}{c}0.436 * * * \\
(6.504)\end{array}$ & & & & & & $\begin{array}{c}0.206 * * \\
(2.120)\end{array}$ & & & \\
\hline Supplier Tang & & & & $\begin{array}{c}3.334 * * * \\
(4.402)\end{array}$ & & & & & & $\begin{array}{c}2.627 * * \\
(2.076)\end{array}$ & & \\
\hline Supplier $R \& D$ & & & & & $\begin{array}{c}30.791 * * * \\
(6.326)\end{array}$ & & & & & & $\begin{array}{l}11.462 \\
(1.419)\end{array}$ & \\
\hline Supplier Diff Goods & & & & & & $\begin{array}{c}0.680 * * * \\
(3.509)\end{array}$ & & & & & & $\begin{array}{l}0.578 * \\
(1.873)\end{array}$ \\
\hline Year Dummies & Yes & Yes & Yes & Yes & Yes & Yes & Yes & Yes & Yes & Yes & Yes & Yes \\
\hline Industry Fixed Effects & No & No & No & No & No & No & Yes & Yes & Yes & Yes & Yes & Yes \\
\hline \# Obs & 26,415 & 26,430 & 26,427 & 26,427 & 26,430 & 26,430 & 26,415 & 26,430 & 26,427 & 26,427 & 26,430 & 26,430 \\
\hline Adjusted R2 & 0.016 & 0.005 & 0.010 & 0.007 & 0.011 & 0.007 & 0.038 & 0.027 & 0.027 & 0.027 & 0.027 & 0.027 \\
\hline
\end{tabular}


Panel B:

\begin{tabular}{|c|c|c|c|c|}
\hline & \multicolumn{4}{|c|}{ PO Indicator } \\
\hline & \multicolumn{2}{|c|}{ Logit } & \multicolumn{2}{|c|}{ Industry Fixed Effects } \\
\hline & (1) & (2) & (3) & (4) \\
\hline \multirow[t]{2}{*}{ High Firm ROA } & $0.542 * * *$ & 0.092 & $0.583 * * *$ & 0.080 \\
\hline & $(9.027)$ & $(1.418)$ & $(9.689)$ & $(1.238)$ \\
\hline \multirow[t]{2}{*}{ High Supplier Herf } & -0.019 & -0.074 & -0.051 & -0.026 \\
\hline & $(-0.276)$ & $(-1.008)$ & $(-0.579)$ & $(-0.288)$ \\
\hline \multirow[t]{2}{*}{ High Supplier Z Scores } & $0.150 * *$ & $0.227 * * *$ & -0.038 & -0.012 \\
\hline & $(2.348)$ & $(3.277)$ & $(-0.515)$ & $(-0.156)$ \\
\hline \multirow[t]{2}{*}{ High Supplier Tangibility } & $0.203 * * *$ & $0.147 * *$ & 0.072 & 0.105 \\
\hline & $(3.010)$ & $(2.050)$ & $(0.829)$ & (1.174) \\
\hline \multirow[t]{2}{*}{ High Supplier R\&D } & 0.046 & 0.055 & 0.036 & 0.032 \\
\hline & $(0.767)$ & $(0.878)$ & $(0.548)$ & $(0.474)$ \\
\hline \multirow[t]{2}{*}{ High Supplier Diff. Goods } & 0.073 & 0.081 & $0.114 *$ & 0.106 \\
\hline & $(1.186)$ & $(1.241)$ & $(1.766)$ & $(1.569)$ \\
\hline \multirow[t]{2}{*}{$\%$ Input Traded } & & $-1.684 * * *$ & & $-1.133^{* *}$ \\
\hline & & $(-3.615)$ & & $(-2.119)$ \\
\hline \multirow[t]{2}{*}{ Leverage } & & $-1.090 * *$ & & $-1.083^{* *}$ \\
\hline & & $(-2.493)$ & & $(-2.436)$ \\
\hline \multirow[t]{2}{*}{ Leverage Squared } & & 0.534 & & 0.477 \\
\hline & & $(0.885)$ & & $(0.778)$ \\
\hline \multirow[t]{2}{*}{ Cash } & & 0.098 & & 0.076 \\
\hline & & $(0.522)$ & & $(0.400)$ \\
\hline \multirow[t]{2}{*}{ Sales } & & $0.208 * * *$ & & $0.164 * * *$ \\
\hline & & $(4.440)$ & & $(3.033)$ \\
\hline \multirow[t]{2}{*}{$R \& D$ Intensity } & & 0.065 & & -0.081 \\
\hline & & $(0.254)$ & & $(-0.279)$ \\
\hline \multirow[t]{2}{*}{ CapEx } & & 0.065 & & $1.481 * * *$ \\
\hline & & $(0.139)$ & & $(2.805)$ \\
\hline \multirow[t]{2}{*}{ Firm Size } & & $0.270 * * *$ & & $0.280^{* * *}$ \\
\hline & & (13.937) & & (13.934) \\
\hline \multirow[t]{2}{*}{ Trade Credit } & & $-1.343 * * *$ & & $-1.045^{* *}$ \\
\hline & & $(-3.370)$ & & $(-2.297)$ \\
\hline Year Dummies & Yes & Yes & Yes & Yes \\
\hline Industry Fixed Effects & No & No & Yes & Yes \\
\hline \# Obs & 20,285 & 19,677 & 20,285 & 19,677 \\
\hline Pseudo R2 & 0.015 & 0.053 & 0.035 & 0.072 \\
\hline
\end{tabular}




\section{Table 4}

\section{Summary statistics - by Steel Exposure}

The tables presents summary statistics using all nonfinancial Compustat firms from 2003-2010. The sample is split on steel exposure with exposure equaling one if steel is greater than $1 \%$ of inputs as identified by the BEA IO tables. P-Values for the differences in means and medians are presented. Other variables are as defined in Table 1.

\begin{tabular}{|c|c|c|c|c|c|c|c|c|c|c|}
\hline & \multicolumn{4}{|c|}{ Steel Exposure } & \multicolumn{4}{|c|}{ No Steel Exposure } & \multirow{2}{*}{$\begin{array}{c}\text { Diff in Means } \\
\text { P Value }\end{array}$} & \multirow{2}{*}{$\begin{array}{c}\text { Diff in Median } \\
\text { P Value }\end{array}$} \\
\hline & \# Obs & Mean & Median & StdError & \# Obs & Mean & Median & StdError & & \\
\hline Firm Size & 6303 & 5.757 & 5.793 & 0.026 & 20127 & 5.740 & 5.752 & 0.015 & 0.59 & 0.31 \\
\hline Sales/Assets & 5970 & 1.034 & 0.961 & 0.008 & 19129 & 1.017 & 0.801 & 0.006 & 0.18 & 0.00 \\
\hline CAPEX/Assets & 5959 & 0.044 & 0.028 & 0.001 & 18696 & 0.052 & 0.029 & 0.001 & 0.00 & 0.12 \\
\hline Market Leverage & 5941 & 0.165 & 0.097 & 0.003 & 19085 & 0.202 & 0.126 & 0.003 & 0.00 & 0.00 \\
\hline Cash/Assets & 5934 & 0.144 & 0.093 & 0.002 & 19001 & 0.156 & 0.087 & 0.001 & 0.00 & 0.01 \\
\hline Trade Credit & 5971 & 0.086 & 0.067 & 0.001 & 19088 & 0.101 & 0.051 & 0.001 & 0.00 & 0.00 \\
\hline
\end{tabular}




\section{Table 5}

\section{Natural Experiment}

The table presents multivariate estimates using nonfinancial Compustat firms from 2003-2010. The dependent variable in the logit estimates in models 1-3 is Commodity Hedger and the OLS estimates in models 4-6 is AggregatePO/Assets. Steel Futures Available is an indicator equal to one if the year is after 2008, zero otherwise. Steel Exposure is equal to one if percentage input from steel is greater than the 1\%, zero otherwise. All control variables are as described in Table 1 and included with a one year lag. Post-event firm control variables (after 2007) are scaled by 2007 total assets. $t$-Statistics are presented in parenthesis and are calculated from robust standard errors clustered by firm. All models include year and firm indicator variables. *, **, and *** represent significance at the $10 \%, 5 \%$, and $1 \%$ levels, respectively.

\begin{tabular}{|c|c|c|c|c|c|c|}
\hline & \multicolumn{3}{|c|}{ Commodity Hedger } & \multicolumn{3}{|c|}{ Aggregate PO/Assets } \\
\hline & (1) & (2) & (3) & (4) & (5) & (6) \\
\hline Steel Futures Available & $\begin{array}{c}0.710 * * * \\
(4.760)\end{array}$ & $\begin{array}{c}0.347 * * \\
(2.305)\end{array}$ & $\begin{array}{c}0.305^{* *} \\
(1.985)\end{array}$ & $\begin{array}{c}0.023 * * * \\
(3.186)\end{array}$ & $\begin{array}{c}0.008 \\
(1.092)\end{array}$ & $\begin{array}{c}0.009 \\
(1.110)\end{array}$ \\
\hline Futures Available*Steel Exposure & $\begin{array}{c}0.467 * * \\
(2.515)\end{array}$ & $\begin{array}{c}0.328 \\
(1.609)\end{array}$ & $\begin{array}{l}0.359^{*} \\
(1.750)\end{array}$ & $\begin{array}{c}-0.030 * * * \\
(-3.096)\end{array}$ & $\begin{array}{c}-0.026 * * \\
(-2.468)\end{array}$ & $\begin{array}{c}-0.027 * * \\
(-2.478)\end{array}$ \\
\hline Leverage & & $\begin{array}{c}-0.239 \\
(-0.561)\end{array}$ & $\begin{array}{c}-0.757 \\
(-0.744)\end{array}$ & & $\begin{array}{c}-0.020 \\
(-0.895)\end{array}$ & $\begin{array}{c}-0.015 \\
(-0.303)\end{array}$ \\
\hline Cash & & $\begin{array}{c}0.221 \\
(0.408)\end{array}$ & $\begin{array}{c}0.322 \\
(0.567)\end{array}$ & & $\begin{array}{c}-0.026 \\
(-1.294)\end{array}$ & $\begin{array}{c}-0.027 \\
(-1.312)\end{array}$ \\
\hline Firm Size & & $\begin{array}{c}0.199 \\
(1.495)\end{array}$ & $\begin{array}{c}0.288 * * \\
(2.063)\end{array}$ & & $\begin{array}{c}-0.001 \\
(-0.091)\end{array}$ & $\begin{array}{c}-0.001 \\
(-0.165)\end{array}$ \\
\hline Capex & & $\begin{array}{c}0.910 \\
(0.904)\end{array}$ & $\begin{array}{c}0.637 \\
(0.610)\end{array}$ & & $\begin{array}{c}0.006 \\
(0.103)\end{array}$ & $\begin{array}{c}0.008 \\
(0.144)\end{array}$ \\
\hline$\%$ Input Traded (non-steel) & & & $\begin{array}{c}1.554 \\
(1.509)\end{array}$ & & & $\begin{array}{c}-0.017 \\
(-0.330)\end{array}$ \\
\hline Leverage Squared & & & $\begin{array}{c}0.780 \\
(0.646)\end{array}$ & & & $\begin{array}{c}-0.005 \\
(-0.086)\end{array}$ \\
\hline Sales & & & $\begin{array}{c}0.352 * * \\
(2.233)\end{array}$ & & & $\begin{array}{c}0.001 \\
(0.142)\end{array}$ \\
\hline$R \& D$ Intensity & & & $\begin{array}{c}1.667 \\
(1.503)\end{array}$ & & & $\begin{array}{c}-0.005 \\
(-0.142)\end{array}$ \\
\hline Trade Credit & & & $\begin{array}{c}-0.746 \\
(-0.601)\end{array}$ & & & $\begin{array}{c}-0.025 \\
(-0.423)\end{array}$ \\
\hline Firm Fixed Effects & Yes & Yes & Yes & Yes & Yes & Yes \\
\hline Year Dummies & Yes & Yes & Yes & Yes & Yes & Yes \\
\hline \# Obs & 4,437 & 3,160 & 3,150 & 25,358 & 20,419 & 20,377 \\
\hline Pseudo/Adjusted R2 & 0.038 & 0.053 & 0.057 & 0.176 & 0.198 & 0.197 \\
\hline
\end{tabular}


Table 6

\section{Placebo Tests}

The table presents placebo tests based on the Steel shock. In the first two columns, we identify industries with no steel exposure (2-digit SIC codes 8, 9, 21, 31, 59,81 ) and examine the reaction of firms in these industries (labeled 'Placebo Exposure') to the introduction of steel futures. In last four columns, the placebo test uses the two years subsequent to the introduction of steel futures as the shock years (2006, 2007), labeled 'Placebo Futures Available'. The firm control variables are Leverage, Cash, Firm Size, and CapEx and are the same as in Columns 2 and 5 of Table 5. The 'Extended Controls', from Table 5 Columns 3 and 6, are \% Input Traded, Leverage Squared, Sales/Assets, R\&D Intensity, and Trade Credit. Post-event firm control variables (after 2007) are scaled by 2007 total assets. These control variables are included in the regressions but omitted in the table for brevity. All models include year and firm indicator variables. *, **, and *** represent significance at the $10 \%, 5 \%$, and $1 \%$ levels, respectively.

\begin{tabular}{|c|c|c|c|c|c|c|}
\hline & \multicolumn{6}{|c|}{ Aggregate PO/Assets } \\
\hline & \multicolumn{2}{|c|}{ All Years } & \multicolumn{2}{|c|}{ All Years } & \multicolumn{2}{|c|}{ Exclude 2008+ } \\
\hline & (1) & (2) & (3) & (4) & (5) & (6) \\
\hline \multirow[t]{2}{*}{ Steel Futures Available } & 0.008 & 0.009 & & & & \\
\hline & $(1.075)$ & $(1.088)$ & & & & \\
\hline \multirow[t]{2}{*}{ Placebo Exposure*Futures Available } & 0.030 & 0.030 & & & & \\
\hline & $(0.614)$ & $(0.622)$ & & & & \\
\hline \multirow[t]{2}{*}{ Placebo Futures Available } & & & 0.002 & 0.002 & 0.001 & 0.001 \\
\hline & & & $(0.285)$ & $(0.301)$ & $(0.219)$ & $(0.232)$ \\
\hline \multirow[t]{2}{*}{ Exposure*Placebo Futures Available } & & & 0.006 & 0.006 & -0.007 & -0.006 \\
\hline & & & $(0.611)$ & $(0.615)$ & $(-0.900)$ & $(-0.750)$ \\
\hline Firm Controls & Yes & Yes & Yes & Yes & Yes & Yes \\
\hline Extended Controls & No & Yes & No & Yes & No & Yes \\
\hline Firm Fixed Effects & Yes & Yes & Yes & Yes & Yes & Yes \\
\hline Year Dummies & Yes & Yes & Yes & Yes & Yes & Yes \\
\hline \# Obs & 20,421 & 20,379 & 20,421 & 20,379 & 12,658 & 12,635 \\
\hline Adjusted R2 & 0.197 & 0.196 & 0.127 & 0.127 & 0.127 & 0.127 \\
\hline
\end{tabular}




\section{Table 7}

\section{Natural Experiment - Matching}

The table presents difference-in-difference results using a matched sample between treated and untreated firms using the steel futures shock. We examine the change in average Aggregate PO/Assets from the 2006, 2007 pre-event window to the 2009, 2010 post-event. In Panel A, we present average Cash, CAPEX, Firm Size, and Leverage for the treated and control firms in the pre-event period (2006, 2007). Panel B presents the basic difference in difference result for the matched sample while Panel $\mathrm{C}$ presents the Average Treatment Effect on the Treated with a bias correction for the imperfect matching. *,**, and *** represent significance at the $10 \%, 5 \%$, and $1 \%$ levels, respectively.

\section{Panel A - Matched Samples}

\begin{tabular}{|c|c|c|c|c|c|c|c|c|}
\hline & \multicolumn{3}{|c|}{ Treated Obs } & \multicolumn{3}{|c|}{ Matched Controls } & \multirow[b]{2}{*}{ Diff } & \multirow[b]{2}{*}{ P Value } \\
\hline & \# Obs & Mean & Std Error & \# Obs & Mean & Std Error & & \\
\hline Cash $_{2006,2007}$ & 604 & 0.126 & 0.005 & 604 & 0.122 & 0.005 & $-0.004 * * *$ & 0.001 \\
\hline CAPEX $_{2006,2007}$ & 604 & 0.052 & 0.002 & 604 & 0.050 & 0.002 & $-0.001 * *$ & 0.016 \\
\hline Firm Size $_{2006,2007}$ & 604 & 6.129 & 0.076 & 604 & 6.145 & 0.074 & 0.016 & 0.266 \\
\hline Leverage $_{2006,2007}$ & 604 & 0.148 & 0.007 & 604 & 0.147 & 0.007 & -0.001 & 0.716 \\
\hline
\end{tabular}

Panel B - Diff in Diff

\begin{tabular}{lrlrrrr}
\hline & \multicolumn{2}{c}{ Pre-Shock } & \multicolumn{2}{c}{ Post-Shock } & \multicolumn{2}{c}{ Difference } \\
\hline Treated & 0.028 & $* * *$ & 0.037 & $* * *$ & 0.009 & $*$ \\
& $(0.004)$ & & $(0.004)$ & & $(0.004)$ & \\
Control & 0.016 & $* * *$ & 0.036 & $* * *$ & 0.021 & $* * *$ \\
& $(0.002)$ & & $(0.008)$ & & $(0.006)$ & \\
\hline Difference & 0.012 & $* *$ & 0.001 & -0.012 & $*$ \\
& $(0.005)$ & & $(0.008)$ & & $(0.007)$ & \\
\hline
\end{tabular}

Panel C - ATT Results

\begin{tabular}{cccccc}
\hline & \# Obs & Coef & Std Error & $\mathrm{z}$ & P Value \\
\hline Aggregate PO/Assets & 2467 & $-0.012^{*}$ & 0.006 & -1.92 & 0.055 \\
\hline
\end{tabular}




\section{Table 8}

\section{Natural Experiment by Collateral and Financial Health}

The table presents multivariate estimates using nonfinancial Compustat firms from 2003-2010. The dependent variable in the logit estimates in models 1-4 is Commodity Hedger and the OLS estimates in models 5-8 is AggregatePO/Assets. A firm's $Z$ Score is 'high' if $\mathrm{Z}>3$ and low otherwise. Tangibility is 'high' if above the industry year mean. Steel Futures Available and Steel Exposure are described in Table 6. All control variables are as described in Table 1 and included with a one year lag. Post-event firm control variables (after 2007) are scaled by 2007 total assets. $t$-Statistics are presented in parenthesis and are calculated from robust standard errors clustered by firm. All models include year and firm indicator variables. *,**, and $* * *$ represent significance at the $10 \%, 5 \%$, and $1 \%$ levels, respectively.

\begin{tabular}{|c|c|c|c|c|c|c|c|c|}
\hline & \multicolumn{4}{|c|}{ Commodity Hedger } & \multicolumn{4}{|c|}{ Aggregate PO/Assets } \\
\hline & \multicolumn{2}{|c|}{ Z Score } & \multicolumn{2}{|c|}{ Tangibility } & \multicolumn{2}{|c|}{ Z Score } & \multicolumn{2}{|c|}{ Tangibility } \\
\hline & High & Low & High & Low & High & Low & High & Low \\
\hline & (1) & (2) & (3) & (4) & (5) & (6) & (7) & (8) \\
\hline \multirow{2}{*}{$\begin{array}{l}\text { Steel Futures } \\
\text { Available }\end{array}$} & 0.217 & $0.508^{*}$ & 0.123 & 0.355 & 0.008 & $0.009 * *$ & -0.002 & $0.012 * * *$ \\
\hline & $(1.042)$ & $(1.845)$ & $(0.528)$ & $(1.381)$ & $(0.676)$ & (1.973) & $(-0.121)$ & $(3.892)$ \\
\hline Steel Exposure & $0.464^{*}$ & -0.045 & $0.936^{* * *}$ & 0.134 & $-0.036^{* *}$ & 0.004 & $-0.054 * *$ & -0.005 \\
\hline *Futures Avail. & (1.778) & $(-0.110)$ & $(2.705)$ & $(0.432)$ & $(-2.382)$ & $(0.586)$ & $(-2.186)$ & $(-1.245)$ \\
\hline \multirow[t]{2}{*}{$\%$ Input Traded } & 1.501 & 1.915 & 1.239 & 2.368 & -0.047 & 0.016 & -0.026 & -0.020 \\
\hline & (1.017) & $(1.238)$ & $(1.003)$ & $(1.066)$ & $(-0.550)$ & $(0.643)$ & $(-0.236)$ & $(-0.806)$ \\
\hline \multirow[t]{2}{*}{ Leverage } & -1.677 & 0.726 & 0.139 & -2.458 & 0.059 & -0.045 & -0.000 & -0.003 \\
\hline & $(-1.060)$ & $(0.378)$ & $(0.092)$ & $(-1.438)$ & $(0.674)$ & $(-1.620)$ & $(-0.000)$ & $(-0.134)$ \\
\hline \multirow[t]{2}{*}{ Leverage Squared } & 1.516 & -0.305 & 0.179 & 2.759 & -0.181 & 0.048 & -0.023 & 0.006 \\
\hline & $(0.603)$ & $(-0.154)$ & $(0.102)$ & $(1.347)$ & $(-1.299)$ & (1.585) & $(-0.171)$ & $(0.211)$ \\
\hline \multirow[t]{2}{*}{ Cash } & 0.294 & 0.909 & 0.602 & 0.424 & -0.033 & -0.003 & -0.083 & -0.011 \\
\hline & $(0.400)$ & $(0.730)$ & $(0.506)$ & $(0.556)$ & $(-1.163)$ & $(-0.201)$ & $(-1.281)$ & $(-1.569)$ \\
\hline \multirow[t]{2}{*}{ Sales } & 0.220 & $1.078 * * *$ & $0.603 * *$ & $0.458^{*}$ & -0.003 & 0.006 & -0.020 & 0.002 \\
\hline & (1.168) & (2.694) & $(2.212)$ & $(1.650)$ & $(-0.237)$ & (1.153) & $(-1.128)$ & $(0.548)$ \\
\hline \multirow[t]{2}{*}{$R \& D$ Intensity } & 1.420 & 2.217 & 2.394 & 1.952 & -0.011 & 0.011 & -0.026 & -0.002 \\
\hline & $(0.782)$ & (1.215) & $(1.200)$ & $(1.415)$ & $(-0.190)$ & $(0.623)$ & $(-0.251)$ & $(-0.191)$ \\
\hline \multirow[t]{2}{*}{ CapEx } & 0.814 & 0.047 & 0.772 & 0.641 & 0.005 & 0.010 & 0.045 & $-0.072 * *$ \\
\hline & $(0.514)$ & $(0.028)$ & $(0.471)$ & $(0.325)$ & $(0.055)$ & $(0.355)$ & $(0.407)$ & $(-2.298)$ \\
\hline \multirow[t]{2}{*}{ Firm Size } & $0.398^{*}$ & -0.161 & $0.657 * *$ & 0.150 & -0.002 & 0.002 & -0.006 & -0.002 \\
\hline & $(1.815)$ & $(-0.641)$ & $(2.504)$ & $(0.705)$ & $(-0.206)$ & $(0.530)$ & $(-0.337)$ & $(-0.910)$ \\
\hline \multirow[t]{2}{*}{ Trade Credit } & 0.422 & -2.998 & -1.126 & -3.635 & -0.043 & 0.002 & -0.111 & 0.033 \\
\hline & $(0.243)$ & $(-0.974)$ & $(-0.571)$ & $(-1.577)$ & $(-0.442)$ & $(0.071)$ & $(-0.902)$ & (1.203) \\
\hline Year Dummies & Yes & Yes & Yes & Yes & Yes & Yes & Yes & Yes \\
\hline Firm Fixed Eff. & Yes & Yes & Yes & Yes & Yes & Yes & Yes & Yes \\
\hline \# Obs & 1,801 & 913 & 1,385 & 1,184 & 14,414 & 5,963 & 9,705 & 9,842 \\
\hline Adjusted R2 & 0.064 & 0.065 & 0.095 & 0.053 & 0.157 & 0.470 & 0.121 & 0.487 \\
\hline
\end{tabular}




\section{Table 9}

\section{Natural Experiment by Bargaining Power}

The table presents multivariate estimates using nonfinancial Compustat firms from 2003-2010. The dependent variable is AggregatePO/Assets. High (Low) Supplier Industry Concentration is defined as having a supplier HHI greater (less) than the annual mean. High (Low) Firm Profitability is defined as having a ROA greater (less) than the annual mean. Steel Futures Available and Steel Exposure are described in Table 6. All control variables are as described in Table 1 and included with a one year lag. Post-event firm control variables (after 2007) are scaled by 2007 total assets. $t$-Statistics are presented in parenthesis and are calculated from robust standard errors clustered by firm. All models include year and firm indicator variables. *, **, and *** represent significance at the $10 \%, 5 \%$, and $1 \%$ levels, respectively.

\begin{tabular}{|c|c|c|c|c|}
\hline & \multicolumn{4}{|c|}{ Aggregate PO/Assets } \\
\hline & \multicolumn{2}{|c|}{ Supplier Ind Concentration } & \multicolumn{2}{|c|}{ Firm Profitability } \\
\hline & High & Low & High & Low \\
\hline & (1) & (2) & (3) & (4) \\
\hline \multirow[t]{2}{*}{ Steel Futures Available } & 0.005 & 0.009 & 0.007 & $0.019 * *$ \\
\hline & $(0.567)$ & $(0.710)$ & $(0.670)$ & $(2.219)$ \\
\hline \multirow[t]{2}{*}{ Steel Exposure*Futures Available } & -0.021 & $-0.027 *$ & $-0.032 * *$ & -0.016 \\
\hline & $(-0.847)$ & $(-1.789)$ & $(-2.206)$ & $(-1.356)$ \\
\hline \multirow[t]{2}{*}{$\%$ Input Traded } & 0.044 & -0.018 & -0.025 & 0.021 \\
\hline & $(0.285)$ & $(-0.278)$ & $(-0.358)$ & $(0.401)$ \\
\hline \multirow[t]{2}{*}{ Leverage } & 0.017 & -0.045 & -0.006 & -0.036 \\
\hline & $(0.288)$ & $(-0.553)$ & $(-0.075)$ & $(-0.869)$ \\
\hline \multirow[t]{2}{*}{ Leverage Squared } & -0.052 & 0.048 & -0.022 & 0.034 \\
\hline & $(-0.718)$ & $(0.438)$ & $(-0.211)$ & $(0.707)$ \\
\hline \multirow[t]{2}{*}{ Cash } & -0.020 & -0.030 & -0.028 & -0.020 \\
\hline & $(-0.841)$ & $(-0.923)$ & $(-0.914)$ & $(-1.329)$ \\
\hline \multirow[t]{2}{*}{ Sales } & $0.014 *$ & -0.017 & -0.007 & $0.010^{*}$ \\
\hline & $(1.667)$ & $(-1.155)$ & $(-0.555)$ & $(1.750)$ \\
\hline \multirow[t]{2}{*}{$R \& D$ Intensity } & -0.023 & 0.006 & 0.004 & -0.025 \\
\hline & $(-0.546)$ & $(0.111)$ & $(0.056)$ & $(-1.390)$ \\
\hline \multirow[t]{2}{*}{ CapEx } & 0.025 & 0.008 & 0.010 & 0.019 \\
\hline & $(0.360)$ & $(0.082)$ & $(0.116)$ & $(0.414)$ \\
\hline \multirow[t]{2}{*}{ Firm Size } & -0.002 & -0.001 & 0.000 & $-0.009 *$ \\
\hline & $(-0.266)$ & $(-0.070)$ & $(0.016)$ & $(-1.693)$ \\
\hline \multirow[t]{2}{*}{ Trade Credit } & -0.026 & -0.034 & -0.055 & -0.034 \\
\hline & $(-0.401)$ & $(-0.335)$ & $(-0.548)$ & $(-0.872)$ \\
\hline Year Dummies & Yes & Yes & Yes & Yes \\
\hline Firm Fixed Effects & Yes & Yes & Yes & Yes \\
\hline \# Obs & 8,691 & 11,686 & 15,280 & 5,097 \\
\hline Adjusted R2 & 0.238 & 0.143 & 0.149 & 0.394 \\
\hline
\end{tabular}




\section{Table 10}

\section{Natural Experiment by Settlement Risk}

The table presents multivariate estimates using nonfinancial Compustat firms from 2003-2010. The dependent variable is AggregatePO/Assets. High (Low) Supplier Z Score is defined as having supplier Z score greater (less) than the industry annual mean. High (Low) Supplier Tangibility is defined as having supplier tangibility greater (less) than the industry annual mean. Long PO Contract equals one if the firm has a purchase obligation written for 3 or more years. Steel Futures Available and Steel Exposure are described in Table 6. All control variables are as described in Table 1 and included with a one year lag. Post-event firm control variables (after 2007) are scaled by 2007 total assets.. $t$-Statistics are presented in parenthesis and are calculated from robust standard errors clustered by firm. All models include year and firm indicator variables. ${ }^{* * *}$, and $* * *$ represent significance at the $10 \%, 5 \%$, and $1 \%$ levels, respectively.

\begin{tabular}{|c|c|c|c|c|c|c|}
\hline & \multicolumn{6}{|c|}{ Aggregate PO/Assets } \\
\hline & \multicolumn{2}{|c|}{ Supplier Z Score } & \multicolumn{2}{|c|}{ Supplier Tangibility } & \multicolumn{2}{|c|}{ Long PO Contract } \\
\hline & $\begin{array}{l}\text { High } \\
\text { (1) }\end{array}$ & $\begin{array}{l}\text { Low } \\
(2)\end{array}$ & $\begin{array}{l}\text { High } \\
\text { (3) }\end{array}$ & $\begin{array}{l}\text { Low } \\
(4)\end{array}$ & $\begin{array}{c}3+\text { Yrs } \\
(5)\end{array}$ & $\begin{array}{c}\text { Shorter } \\
(6)\end{array}$ \\
\hline Steel Futures Available & $\begin{array}{c}0.009 \\
(0.632)\end{array}$ & $\begin{array}{c}0.007 \\
(0.911)\end{array}$ & $\begin{array}{c}0.019 \\
(1.139)\end{array}$ & $\begin{array}{c}0.003 \\
(0.486)\end{array}$ & $\begin{array}{c}0.055 \\
(1.276)\end{array}$ & $\begin{array}{c}0.007 \\
(0.982)\end{array}$ \\
\hline Steel Exposure*Futures Available & $\begin{array}{c}-0.033^{* *} \\
(-1.985)\end{array}$ & $\begin{array}{c}0.002 \\
(0.116)\end{array}$ & $\begin{array}{l}-0.041^{* *} \\
(-2.197)\end{array}$ & $\begin{array}{c}0.001 \\
(0.086)\end{array}$ & $\begin{array}{c}-0.191 * * \\
(-2.378)\end{array}$ & $\begin{array}{c}-0.006 \\
(-0.562)\end{array}$ \\
\hline$\%$ Input Traded & $\begin{array}{c}-0.066 \\
(-0.640)\end{array}$ & $\begin{array}{c}0.003 \\
(0.051)\end{array}$ & $\begin{array}{c}-0.012 \\
(-0.167)\end{array}$ & $\begin{array}{c}-0.877 * * * \\
(-3.158)\end{array}$ & $\begin{array}{c}-0.407 \\
(-1.112)\end{array}$ & $\begin{array}{c}-0.031 \\
(-0.214)\end{array}$ \\
\hline Leverage & $\begin{array}{c}-0.015 \\
(-0.169)\end{array}$ & $\begin{array}{c}-0.014 \\
(-0.241)\end{array}$ & $\begin{array}{c}-0.050 \\
(-0.512)\end{array}$ & $\begin{array}{c}0.012 \\
(0.236)\end{array}$ & $\begin{array}{c}-0.003 \\
(-0.007)\end{array}$ & $\begin{array}{c}-0.028 \\
(-0.487)\end{array}$ \\
\hline Leverage Squared & $\begin{array}{c}-0.014 \\
(-0.122)\end{array}$ & $\begin{array}{c}-0.015 \\
(-0.219)\end{array}$ & $\begin{array}{c}0.036 \\
(0.293)\end{array}$ & $\begin{array}{c}-0.043 \\
(-0.686)\end{array}$ & $\begin{array}{c}-0.120 \\
(-0.203)\end{array}$ & $\begin{array}{c}-0.058 \\
(-0.716)\end{array}$ \\
\hline Cash & $\begin{array}{c}-0.031 \\
(-0.941)\end{array}$ & $\begin{array}{c}-0.026 \\
(-1.067)\end{array}$ & $\begin{array}{c}-0.060 \\
(-1.220)\end{array}$ & $\begin{array}{c}-0.015 \\
(-0.891)\end{array}$ & $\begin{array}{l}-0.361 * \\
(-1.684)\end{array}$ & $\begin{array}{c}0.057 * * \\
(2.564)\end{array}$ \\
\hline Sales & $\begin{array}{c}-0.009 \\
(-0.592)\end{array}$ & $\begin{array}{c}0.008 \\
(0.862)\end{array}$ & $\begin{array}{c}-0.003 \\
(-0.173)\end{array}$ & $\begin{array}{c}0.005 \\
(0.708)\end{array}$ & $\begin{array}{l}-0.163 * \\
(-1.870)\end{array}$ & $\begin{array}{c}0.038 * * * \\
(4.115)\end{array}$ \\
\hline$R \& D$ Intensity & $\begin{array}{c}-0.004 \\
(-0.085)\end{array}$ & $\begin{array}{c}-0.027 \\
(-0.554)\end{array}$ & $\begin{array}{c}0.002 \\
(0.017)\end{array}$ & $\begin{array}{c}-0.006 \\
(-0.226)\end{array}$ & $\begin{array}{c}-0.004 \\
(-0.010)\end{array}$ & $\begin{array}{c}-0.114 * * \\
(-2.083)\end{array}$ \\
\hline CapEx & $\begin{array}{c}-0.006 \\
(-0.052)\end{array}$ & $\begin{array}{c}0.016 \\
(0.307)\end{array}$ & $\begin{array}{c}0.013 \\
(0.112)\end{array}$ & $\begin{array}{c}0.011 \\
(0.200)\end{array}$ & $\begin{array}{c}0.413 \\
(0.696)\end{array}$ & $\begin{array}{c}-0.091 \\
(-1.405)\end{array}$ \\
\hline Firm Size & $\begin{array}{c}-0.007 \\
(-0.546)\end{array}$ & $\begin{array}{c}0.000 \\
(0.053)\end{array}$ & $\begin{array}{c}-0.006 \\
(-0.380)\end{array}$ & $\begin{array}{c}0.003 \\
(0.434)\end{array}$ & $\begin{array}{c}0.001 \\
(0.018)\end{array}$ & $\begin{array}{c}-0.009 \\
(-1.299)\end{array}$ \\
\hline Trade Credit & $\begin{array}{c}-0.039 \\
(-0.379)\end{array}$ & $\begin{array}{c}0.001 \\
(0.017)\end{array}$ & $\begin{array}{c}-0.121 \\
(-0.935)\end{array}$ & $\begin{array}{c}0.026 \\
(0.498)\end{array}$ & $\begin{array}{l}-1.502 * \\
(-1.788)\end{array}$ & $\begin{array}{c}0.395^{* * *} * \\
(5.270)\end{array}$ \\
\hline $\begin{array}{l}\text { Year Dummies } \\
\text { Firm Fixed Effects }\end{array}$ & $\begin{array}{l}\text { Yes } \\
\text { Yes }\end{array}$ & $\begin{array}{l}\text { Yes } \\
\text { Yes }\end{array}$ & $\begin{array}{l}\text { Yes } \\
\text { Yes }\end{array}$ & $\begin{array}{l}\text { Yes } \\
\text { Yes }\end{array}$ & $\begin{array}{l}\text { Yes } \\
\text { Yes }\end{array}$ & $\begin{array}{l}\text { Yes } \\
\text { Yes }\end{array}$ \\
\hline $\begin{array}{l}\text { \# Obs } \\
\text { Adjusted R2 }\end{array}$ & $\begin{array}{c}11,150 \\
0.135\end{array}$ & $\begin{array}{l}9,224 \\
0.215\end{array}$ & $\begin{array}{l}9,422 \\
0.145\end{array}$ & $\begin{array}{c}10,952 \\
0.227\end{array}$ & $\begin{array}{l}2,709 \\
0.280\end{array}$ & $\begin{array}{l}1,992 \\
0.716\end{array}$ \\
\hline
\end{tabular}




\section{Table 11}

\section{Natural Experiment by IO Motivations}

The table presents multivariate estimates using nonfinancial Compustat firms from 2003-2010. The dependent variable is AggregatePO/Assets. High (Low) Supplier $R \& D$ is defined as having supplier R\&D greater (less) than the industry annual mean. High (Low) Differentiated Goods is defined following the methodology of Giannetti et al (2011). Vertically Integrated is defined following the methodology of Acemoglu et al. (2009). Steel Futures Available and Steel Exposure are described in Table 6. All control variables are as described in Table 1 and included with a one year lag. Post-event firm control variables (after 2007) are scaled by 2007 total assets. $t$-Statistics are presented in parenthesis and are calculated from robust standard errors clustered by firm. All models include year and firm indicator variables. $* * *$, and $* * *$ represent significance at the $10 \%, 5 \%$, and $1 \%$ levels, respectively.

\begin{tabular}{|c|c|c|c|c|c|c|}
\hline & \multicolumn{6}{|c|}{ Aggregate PO/Assets } \\
\hline & \multicolumn{2}{|c|}{ Supplier $R \& D$} & \multicolumn{2}{|c|}{ Differentiated Goods } & \multicolumn{2}{|c|}{ Vertically Integrated } \\
\hline & High & Low & Yes & No & VI & No VI \\
\hline & (1) & (2) & (3) & (4) & (5) & (6) \\
\hline \multirow[t]{2}{*}{ Steel Futures Available } & 0.002 & $0.020 * * *$ & 0.005 & $0.020 * * *$ & 0.020 & 0.009 \\
\hline & $(0.286)$ & $(4.886)$ & $(0.691)$ & $(5.247)$ & $(0.954)$ & $(1.075)$ \\
\hline \multirow[t]{2}{*}{ Steel Exposure $*$ Futures Available } & 0.008 & $-0.022 * * *$ & -0.000 & $-0.017 * * *$ & -0.026 & $-0.027 * *$ \\
\hline & $(0.631)$ & $(-3.998)$ & $(-0.040)$ & $(-3.288)$ & $(-0.730)$ & $(-2.420)$ \\
\hline \multirow[t]{2}{*}{$\%$ Input Traded } & 0.061 & -0.016 & -0.048 & -0.005 & -0.023 & -0.018 \\
\hline & $(0.489)$ & $(-0.820)$ & $(-0.349)$ & $(-0.273)$ & $(-0.293)$ & $(-0.327)$ \\
\hline \multirow[t]{2}{*}{ Leverage } & -0.035 & -0.023 & 0.006 & $-0.056 * *$ & -0.172 & -0.012 \\
\hline & $(-0.616)$ & $(-0.895)$ & $(0.111)$ & $(-2.294)$ & $(-1.218)$ & $(-0.240)$ \\
\hline \multirow[t]{2}{*}{ Leverage Squared } & 0.010 & 0.010 & -0.046 & $0.052 *$ & 0.195 & -0.009 \\
\hline & $(0.131)$ & $(0.326)$ & $(-0.654)$ & (1.709) & (1.076) & $(-0.139)$ \\
\hline \multirow[t]{2}{*}{ Cash } & -0.022 & $-0.017 *$ & -0.009 & $-0.027 * * *$ & $0.163 * *$ & -0.029 \\
\hline & $(-0.961)$ & $(-1.664)$ & $(-0.410)$ & $(-2.639)$ & $(2.032)$ & $(-1.387)$ \\
\hline \multirow[t]{2}{*}{ Sales } & 0.003 & -0.004 & 0.008 & $0.008^{*}$ & $0.074 * *$ & 0.001 \\
\hline & $(0.337)$ & $(-0.990)$ & $(0.986)$ & (1.959) & $(2.203)$ & $(0.080)$ \\
\hline \multirow[t]{2}{*}{$R \& D$ Intensity } & 0.003 & -0.000 & -0.008 & 0.008 & 0.168 & -0.007 \\
\hline & $(0.079)$ & $(-0.024)$ & $(-0.227)$ & $(0.468)$ & (1.138) & $(-0.204)$ \\
\hline \multirow[t]{2}{*}{ CapEx } & -0.012 & 0.021 & 0.010 & -0.043 & -0.168 & 0.011 \\
\hline & $(-0.172)$ & $(0.778)$ & $(0.186)$ & $(-1.382)$ & $(-0.990)$ & $(0.178)$ \\
\hline \multirow[t]{2}{*}{ Firm Size } & 0.005 & -0.001 & 0.002 & $0.007^{* *}$ & 0.045 & -0.002 \\
\hline & $(0.638)$ & $(-0.205)$ & $(0.352)$ & (2.027) & $(1.505)$ & $(-0.234)$ \\
\hline \multirow[t]{2}{*}{ Trade Credit } & 0.061 & 0.050 & -0.023 & $0.115 * * *$ & $-0.398 *$ & -0.025 \\
\hline & $(0.951)$ & $(1.572)$ & $(-0.359)$ & $(3.860)$ & $(-1.683)$ & $(-0.407)$ \\
\hline Year Dummies & Yes & Yes & Yes & Yes & Yes & Yes \\
\hline Firm Fixed Effects & Yes & Yes & Yes & Yes & Yes & Yes \\
\hline \# Obs & 9,738 & 10,639 & 10,043 & 10,334 & 461 & 19,916 \\
\hline Adjusted R2 & 0.780 & 0.378 & 0.777 & 0.416 & 0.279 & 0.194 \\
\hline
\end{tabular}




\section{Table 12}

\section{Natural Experiment and Firm Linkages}

The table presents multivariate estimates using nonfinancial Compustat firms from 2003-2010. The dependent variable is either Trade Credit or Vertically Integrated/Vertical Coefficient (binary or level of integration, respectively). Steel Futures Available and Steel Exposure are described in Table 6. All control variables are as described in Table 1 and included with a one year lag. Post-event firm control variables (after 2007) are scaled by 2007 total assets. $t$-Statistics are presented in parenthesis and are calculated from robust standard errors clustered by firm. All models include year and firm indicator variables. *, **, and *** represent significance at the $10 \%, 5 \%$, and $1 \%$ levels, respectively.

\begin{tabular}{|c|c|c|c|}
\hline & Trade Credit & $\begin{array}{c}\text { Vertically } \\
\text { Integrated }\end{array}$ & Vertical Coefficient \\
\hline & (1) & (2) & (3) \\
\hline \multirow[t]{2}{*}{ Steel Futures Available } & 0.002 & -0.002 & $-0.000^{*}$ \\
\hline & $(1.235)$ & $(-0.600)$ & $(-1.738)$ \\
\hline \multirow[t]{2}{*}{ Steel Exposure*Futures Available } & -0.002 & 0.000 & 0.000 \\
\hline & $(-0.921)$ & $(0.030)$ & $(0.063)$ \\
\hline \multirow[t]{2}{*}{ \% Input Traded } & 0.002 & -0.004 & 0.000 \\
\hline & $(0.142)$ & $(-0.218)$ & $(0.423)$ \\
\hline \multirow[t]{2}{*}{ Leverage } & $0.071 * * *$ & $-0.035^{* *}$ & -0.001 \\
\hline & $(6.785)$ & $(-2.068)$ & $(-1.229)$ \\
\hline \multirow[t]{2}{*}{ Leverage Squared } & $-0.051 * * *$ & $0.050 * *$ & $0.002 * *$ \\
\hline & $(-3.851)$ & $(2.341)$ & $(2.087)$ \\
\hline \multirow[t]{2}{*}{ Cash } & $-0.021 * * *$ & 0.003 & 0.000 \\
\hline & $(-5.157)$ & $(0.490)$ & $(0.697)$ \\
\hline \multirow{2}{*}{ Sales } & $0.008 * * *$ & -0.004 & -0.000 \\
\hline & $(5.271)$ & $(-1.435)$ & $(-0.502)$ \\
\hline \multirow[t]{2}{*}{$R \& D$ Intensity } & $0.062 * * *$ & -0.011 & -0.000 \\
\hline & $(9.790)$ & $(-1.069)$ & $(-1.172)$ \\
\hline \multirow[t]{2}{*}{ CapEx } & -0.016 & 0.004 & -0.000 \\
\hline & $(-1.338)$ & $(0.224)$ & $(-0.214)$ \\
\hline \multirow[t]{2}{*}{ Firm Size } & $-0.028 * * *$ & 0.002 & 0.000 \\
\hline & $(-20.568)$ & $(0.980)$ & (1.288) \\
\hline Year Dummies & Yes & Yes & Yes \\
\hline Firm Fixed Effects & Yes & Yes & Yes \\
\hline \# Obs & 20,721 & 20,766 & 20,766 \\
\hline Adjusted R2 & 0.831 & 0.645 & 0.651 \\
\hline
\end{tabular}

